University of Nebraska - Lincoln

DigitalCommons@University of Nebraska - Lincoln

Publications from USDA-ARS / UNL Faculty

U.S. Department of Agriculture: Agricultural

Research Service, Lincoln, Nebraska

2014

\title{
Metal and nanoparticle occurrence in biosolid-amended soils
}

Yu Yang

Arizona State University at the Tempe Campus, yu.yang.2@asu.edu

Yifei Wang

Arizona State University at the Tempe Campus

Paul Westerhoff

Arizona State University at the Tempe Campus

Kiril Hristovski

Arizona State University

Virginia L. Jin

USDA-ARS, virginia.jin@ars.usda.gov

See next page for additional authors

Follow this and additional works at: https://digitalcommons.unl.edu/usdaarsfacpub

Yang, Yu; Wang, Yifei; Westerhoff, Paul; Hristovski, Kiril; Jin, Virginia L.; Johnson, Mari-Vaughn V.; and Arnold, Jeffrey G., "Metal and nanoparticle occurrence in biosolid-amended soils" (2014). Publications from USDA-ARS / UNL Faculty. 1412.

https://digitalcommons.unl.edu/usdaarsfacpub/1412

This Article is brought to you for free and open access by the U.S. Department of Agriculture: Agricultural Research Service, Lincoln, Nebraska at DigitalCommons@University of Nebraska - Lincoln. It has been accepted for inclusion in Publications from USDA-ARS / UNL Faculty by an authorized administrator of DigitalCommons@University of Nebraska - Lincoln. 


\section{Authors}

Yu Yang, Yifei Wang, Paul Westerhoff, Kiril Hristovski, Virginia L. Jin, Mari-Vaughn V. Johnson, and Jeffrey G. Arnold 


\title{
Metal and nanoparticle occurrence in biosolid-amended soils
}

\author{
Yu Yang a,*, Yifei Wang a , Paul Westerhoff ${ }^{\text {a }}$, Kiril Hristovski ${ }^{\text {b }}$, Virginia L. Jin ${ }^{\text {c }}$, \\ Mari-Vaughn V. Johnson ${ }^{\mathrm{d}}$, Jeffrey G. Arnold ${ }^{\mathrm{e}}$ \\ a School of Sustainable Engineering and the Built Environment, Arizona State University, Tempe, AZ 85287-5306, United States \\ b College of Technology and Innovation, Arizona State University at the Polytechnic Campus, Mesa, AZ 85212, United States \\ c USDA - Agricultural Research Service, University of Nebraska-Lincoln, East Campus, Lincoln, NE 68583-0937, United States \\ ${ }^{d}$ USDA - Natural Resources Conservation Service, Grassland, Soil, and Water Research Laboratory, Temple, TX 76502, United States \\ e USDA - Agricultural Research Service, Grassland, Soil, and Water Research Laboratory, Temple, TX 76502, United States
}

\section{H I G H L I G H T S}

- Biosolid land application increased the unregulated metal contents in surface soil.

- Metals (e.g., Ag) associated with ENMs show accumulation and low mobility in soils.

- Titanium-containing nanoparticle (50 $\mathrm{nm}$ in diameter) was identified in the soils.

\section{A R T I C L E I N F O}

Article history:

Received 24 February 2014

Received in revised form 24 March 2014

Accepted 24 March 2014

Available online $\mathrm{xxxx}$

Editor: D. Barcelo

\section{Keywords:}

Nanomaterials

Titanium

Metal profile

Soil

\begin{abstract}
A B S T R A C T
Metals can accumulate in soils amended with biosolids in which metals have been concentrated during wastewater treatment. The goal of this study is to inspect agricultural sites with long-term biosolid application for a suite of regulated and unregulated metals, including some potentially present as commonly used engineered nanomaterials (ENMs). Sampling occurred in fields at a municipal and a privately operated biosolid recycling facilities in Texas. Depth profiles of various metals were developed for control soils without biosolid amendment and soils with different rates of biosolid application ( 6.6 to 74 dry tons per hectare per year) over 5 to 25 years. Regulated metals of known toxicity, including chromium, copper, cadmium, lead, and zinc, had higher concentrations in the upper layer of biosolid-amended soils (top 0-30 $\mathrm{cm}$ or $0-15 \mathrm{~cm}$ ) than in control soils. The depth profiles of unregulated metals (antimony, hafnium, molybdenum, niobium, gold, silver, tantalum, tin, tungsten, and zirconium) indicate higher concentrations in the $0-30 \mathrm{~cm}$ soil increment than in the $70-100 \mathrm{~cm}$ soil increment, indicating low vertical mobility after entering the soils. Titanium-containing particles between $50 \mathrm{~nm}$ and $250 \mathrm{~nm}$ in diameter were identified in soil by transmission electron microscopy (TEM) coupled with energy dispersive $\mathrm{x}$-ray spectroscopy (EDX) analysis. In conjunction with other studies, this research shows the potential for nanomaterials used in society that enter the sewer system to be removed at municipal biological wastewater treatment plants and accumulate in agricultural fields. The metal concentrations observed herein could be used as representative exposure levels for eco-toxicological studies in these soils.
\end{abstract}

(c) 2014 Elsevier B.V. All rights reserved.

\section{Introduction}

Roughly $40 \%$ of the 7 million dry tons of biosolids (i.e., sewage sludge) produced each year are land applied as supplemental fertilizer or landfill cover in United States (U.S. EPA, 1999). The long-term land application of biosolids has led to concerns about the potential accumulation and ecotoxicity of metals in biosolid-amended soils (Illera et al., 2000; Sloan et al., 1997). The land application of biosolids is currently subject to several metal concentration limits according to the U.S. EPA Part 503 Biosolids Rule, including those for arsenic (As), cadmium

\footnotetext{
* Corresponding author. Tel.: + 14807272913

E-mail address: yu.yang.2@asu.edu (Y. Yang).
}

(Cd), copper $(\mathrm{Cu})$, lead $(\mathrm{Pb})$, mercury $(\mathrm{Hg})$, molybdenum (Mo), nickel (Ni), selenium (Se), and zinc (Zn) (U.S. EPA, 1995). However, despite their widespread use in industry, less information exists on classically unregulated metals (e.g., minor metals, MMs) or rare earth elements (REEs), and metals associated with nanomaterials (Chang et al., 1984; Graedel and Van Der Voet, 2010; Han et al., 2000; Jorg et al., 1999; Tourinho et al., 2012). Engineered nanomaterials (ENMs) that are discharged to sewers and accumulate in biosolids could eventually end up in soils amended with those biosolids (de la Rosa et al., 2011; Judy et al., 2012; Kim et al., 2012). Concerns about ENMs include soil eco-toxicological risks to soil microbial and invertebrate communities, soil runoff, and uptake of nano-and micron-scale metals and metal oxides by plants (de la Rosa et al., 2011; Ge et al., 2011; Judy et al., 
2012), the consumption of which leads to possible accumulation in other organisms. This paper explores the presence of a wide range of metals in biosolid-amended soils and prospects for nano- to micronsized metal materials, potentially of an engineered origin, to be transferred to the soils via wastewater biosolids.

Diverse sources of nanomaterials may lead to ENM accumulation in biosolid-amended soils. Nanosilver and copper in products can be released or sorbed to wastewater biomass (Benn and Westerhoff, 2008; Glover et al., 2011). The estimated concentrations in sludge-treated soils of nano- $\mathrm{TiO}_{2}$ and nano-silver are $42 \mu \mathrm{g} / \mathrm{kg}$ and $662 \mathrm{ng} / \mathrm{kg}$ per year, respectively (Gottschalk et al., 2009). Ecological concerns increase due to the antimicrobial/toxic effects of nano-silver and $\mathrm{TiO}_{2}$ (Choi et al., 2010; Yang et al., 2012a,b), which could inhibit a wide range of microorganisms in the soil environment (Ge et al., 2011; U.S. EPA, 2010; Yang et al., 2013). Determination of the presence of nano-scale metals expected to occur in soils after biosolid application is critical to closing the mass balance of materials from largely anthropogenic sources.

Many factors, including sludge resources, application rate, $\mathrm{pH}$ and other soil properties, organic matter content, and redox potential, affect the accumulation of regulated metals in biosolid-amended soils (Hue and Ranjith, 1994; Singh and Agrawal, 2008; Smith, 2009). However, information on MMs, REEs and/or platinum group elements (PGEs), and ENMs in soils is limited (Gottschalk et al., 2009; Kim et al., 2012; Nowack and Bucheli, 2007). For example, experiments with ENMs demonstrated the presence of $\mathrm{TiO}_{2}$ nanoparticles in biosolids only recently (Kim et al., 2012). Therefore, this study aims to address the following objective-directed questions: (1) what is the extent of metal accumulation in biosolid-amended soils; (2) what are the depth migration patterns of these metals; and (3) do some of the metals manifest as ENMs? To answer these questions, we tested soil samples from two large-scale field sites where biosolids have been applied at different rates and for different periods of time. The samples were processed via a microwave-assisted acid digestion, after which the metal concentration was determined by inductively coupled plasma-mass spectrometry (ICP-MS). The concentrations of regulated, trace, and precious metals were investigated. Transmission electron microscopy (TEM) equipped with energy dispersive x-ray spectroscopy (EDX) was employed to determine the presence of and characterize any metallic ENMs in undigested samples.

\section{Methodology}

\subsection{Study areas and sample collection}

The biosolid-amended soils evaluated in this study were collected at two biosolid land application sites in Texas with permission (Fig. S1).
Site 1 is a 486 hectare (ha), municipally operated biosolid recycling facility in Travis County (Jin et al., 2011). Site 2 is a 243 ha, privately operated biosolid recycling facility in Bell County. Both sites are maintained as continuous, no-tillage forage production systems consisting of coastal Bermuda grass (Cynodon dactylon L.). Forage is harvested three to five times per season depending on rainfall and resultant biomass production. No topsoil is removed during harvest at either site. Biosolids were applied to fields of varying size for a total life-time application area of 220 ha at site 1 and 149 ha at site 2 at the time of sampling, respectively (Table 1 ).

Site 1 soils are classified as fine-silty, mixed, superactive, thermic Cumulic Haplustolls (Bergstrom silt loams and silty clay loams). Soils are very deep ( $>2 \mathrm{~m}$ to groundwater) and well drained, with slopes generally $<1 \%$ (Jin et al., 2011). The 30 -year mean annual temperature at site 1 is $19.6{ }^{\circ} \mathrm{C}$, and the 30 -year mean annual precipitation is 817 mm (1981-2010, National Climate Data Center, http://www.ncdc. noaa.gov/). Volatile solid content for soils at site 1 ranged from $3.6 \%$ to $4.4 \%$ of total dry mass, which were determined from 48 soil samples using standard methods (APHA et al., 2005). At site 1, three subsites have received biosolids at the state-approved application rates of 25 , 49 , and 74 dry tons biosolids per hectare per year (dry tons/ha/y) for 8 years prior to soil sampling; these are named site $1-1,1-2$, and 1-3 in this paper for simplicity (Table 1). Hereafter, treatments are described using these rates, although only $85 \%$ to $95 \%$ of the maximum rates are applied in practice. In addition, a long-term application field (30 ac) (named site 1-4) received biosolids at a rate of 25 dry tons/ha/ $\mathrm{y}$ for 20 years (1985-2005), followed by a reduced application rate of 6.6 dry tons/ha/y every other year in compliance with the facility's current nutrient management plan. Prior to soil sampling, only one application at this lower rate occurred in the long-term field (on year 2007). Control soil was sampled from a 12-ha field without any biosolid application, which was named site 1-control. Samples of the biosolids applied to site 1 (Class B biosolids) were obtained as a random grab sample from a biosolid stockpile on Oct 20th, 2011. This material was the untreated, belt-pressed biosolids which was being stockpiled prior to land application. The material sampled was relatively new (1-2 days old) due to the grab sample coming from the outer surface of the stockpile, the age of which varied from weeks to months depending on time of year and application schedule. Samples of the biosolids were used for metal concentration comparison among control soil, biosolid-amended soil, and biosolids. Biosolid samples from previous years were not available to evaluate metal concentrations over time. Although temporal variation in biosolid metal concentrations can occur (U.S. EPA, 1999), the biosolid grab-sample in this study provides an approximation of potential metal loading concentration for evaluating metal accumulation in biosolid-amended soils.

Table 1

Descriptions of biosolid-applied areas at sites used in this study prior to soil sampling.

\begin{tabular}{|c|c|c|c|c|c|}
\hline \multirow[t]{2}{*}{ Site location } & \multirow[t]{2}{*}{ Sub-site specified } & \multicolumn{4}{|c|}{ Biosolid application description } \\
\hline & & $\begin{array}{l}\text { Area applied } \\
\text { (hectare) }\end{array}$ & $\begin{array}{l}\text { History } \\
\text { (year) }\end{array}$ & $\begin{array}{l}\text { Rate } \\
\text { (dry tons/ha/y) }\end{array}$ & Waste type \\
\hline \multirow[t]{6}{*}{ Site 1 - Travis County } & Site 1-control & 2 & Control & 0 & No applications \\
\hline & Site $1-1$ & 20 & 2002-2009 & 25 & Class B biosolids \\
\hline & Site $1-2$ & 36 & 2002-2009 & 49 & Class B biosolids \\
\hline & Site $1-3$ & 49 & $2002-2009$ & 74 & Class B biosolids \\
\hline & Site $1-4$ & ${ }^{\mathrm{a}} 12$ & 1985-2005 & 25 & Class B biosolids \\
\hline & & & 2007 & 6.6 & Class B biosolids \\
\hline \multirow[t]{6}{*}{ Site 2 - Bell County } & Site 2-A31 & 13 & $2007-2010$ & 6.6 & Class B biosolids \\
\hline & Site 2 -I30 & 12 & $2003-2010$ & 6.6 & Class B biosolids \\
\hline & Site 2-F16 & 6 & $2003-2010$ & 6.6 & Class B biosolids \\
\hline & Site 2 -J22 & 9 & 2000-2005 & 6.6 & Domestic septage \\
\hline & Site 2-D32 & ${ }^{b} 13$ & $1978-1992$ & 6.6 & Domestic septage \\
\hline & & & $1993-2010$ & 6.6 & Class B biosolids \\
\hline
\end{tabular}

\footnotetext{
a Field was applied with 25 dry tons/ha/y (1985-2005), then 6.6 dry tons/ha/y (2007 only).

b Field was applied with domestic septage (1978-1992), then Class B biosolids (1992-2010).
} 
Site 2 soils are classified as a fine-silty, mixed, active, thermic Udic Calciustoll (Lewisville silty clay) and a fine-loamy, mixed, thermic Udic Calciustoll (Venus clay loam). Soils are calcareous (up to $40 \%$ carbonate by weight) and well drained, with slopes of 1-3\% (USDANRCS, 2007). The 30 -year MAT at site 2 is $18.9{ }^{\circ} \mathrm{C}$, and the 30 -year mean annual precipitation is $840 \mathrm{~mm}$ (1981-2010, National Climate Data Center, http://www.ncdc.noaa.gov/). Mean volatile solid content for soil samples at site 2 ranged from $6 \%$ to $10 \%$ of total dry mass analyzed using standard methods (APHA et al., 2005). Waste type and application histories varied, ranging from 4 to 33 years of application (Table 1). The state-approved maximum application rate for biosolids or domestic septage at site 2 was 6.6 dry tons/ha/y. In addition to forage production, site 2 also implemented rotational cattle grazing in all biosolid-applied fields following the required no-entry period of 30 days immediately post-application. Treatment fields from site 2 were historically given IDs of site 2-A31, site 2-I30, site 2-F16, site 2J22, and site 2-D32 (Table 1). We only presented the metal concentration in site 2-D32 with the longest application time of 32 years, and in site 2-F16 with the shortest application time of 8 years, since metal concentrations in the rest of the subsites were within concentration ranges of site 2-F16 to site 2-D32. We did not obtain any control soil or biosolid samples for site 2 . Thus, the metal analysis results from site 2 include only metal abundance and depth profiles.

Sampling depth intervals at site 1 generally matched the generic horizon designations $(0-30 \mathrm{~cm}, 30-70 \mathrm{~cm}$, and 70-100 cm). Sampling intervals at site 2 corresponded with standard soil testing intervals (0-15 cm and 15-60 cm) (Franzen and Cihacek, 1998), as the objective of sampling this site was to provide management recommendations to this private stakeholder who had historical records for nutrients using these soil depth intervals. Soil cores (6.35 $\mathrm{cm}$ diameter) were collected using a truck-mounted hydraulic soil-sampling rig (Giddings Machine Co., Windsor, CO, U.S.). No biosolids had been applied at any sampling location for at least 90 days prior to sampling. Along a transect spanning the center of each treatment field, paired soil cores were collected and composited by depth increment at $15 \mathrm{~m}$ to $50 \mathrm{~m}$ intervals, depending on the size of the field ( $n=4$ composited pairs per treatment for site $1, n=3$ composited pairs per treatment for site 2 ). No cores were taken within $20 \mathrm{~m}$ of the field edge due to possible edge effects (i.e., increased soil compaction due to higher equipment traffic). Visible biosolids and plant material were removed from the soil surface prior to sampling. At site 1 , soils from biosolid-applied fields were sampled at 0-30, 30-70, and 70-100 cm depth increments in September 2009. Control soils were sampled similarly in March 2009. At site 2, soils were sampled at 0-15 and 15-60 cm depth increments in June 2010. For each paired set, soils were composited by depth, passed through $2 \mathrm{~mm}$ sieve, and stored in acid-washed glass jars with clear Teflonlined screw caps. Samples were stored in the dark in a temperaturecontrolled sample archival room until subsampled for further chemical analysis.

\subsection{Chemical analysis}

To determine the metal content in soil, samples were microwave digested according to the standard method $3030 \mathrm{G}$ and then analyzed by ICP-MS (APHA et al., 2005). Air-dried soil and biosolid samples of approximately $0.5 \mathrm{~g}$ were added to a $55 \mathrm{~mL}$ microwave digestion vessel separately, along with $8 \mathrm{~mL}$ of $70 \%$ nitric acid (ULTREX® II Ultrapure Reagent, J.T. Baker, Avantor Materials, PA, U.S.), $4 \mathrm{~mL}$ of hydrochloric acid (33\%-36\% w/w, ULTREX® II Ultrapure Reagent, J.T. Baker, Avantor Materials, PA, U.S.), and $2 \mathrm{~mL}$ of hydrofluoric acid (47-51\% w/w, ULTREX® II Ultrapure Reagent, J.T. Baker, Avantor Materials, PA, USA). The samples in vessels were digested in a Microwave Assisted Reaction System (MARS) Express instrument (MARS 6, CEM, NC, U.S.). After cooling down to room temperature, the vessels were rinsed 3 times using a total of $20 \mathrm{~mL}$ of a $2 \%$ nitric acid solution into a Teflon ${ }^{\circledR}$ beaker. An aliquot of $2 \mathrm{~mL}$ of $30 \%$ hydrogen peroxide (BAKER ANALYZED® A.C.S.
Reagent, Avantor Materials, PA, U.S.) was added to each beaker to digest any remaining organics. The beaker was then heated on a hot plate at $180{ }^{\circ} \mathrm{C}$ until between 1 and $5 \mathrm{~mL}$ of solution remained. The beakers were removed from the hot plate and allowed to cool to room temperature. The beakers were rinsed 3 times with $5 \%$ nitric acid solution into a $100 \mathrm{~mL}$ volumetric flask before being stored for analysis. XSERIE-2 ICPMS (Thermo Scientific, U.S.) was used for metal content analysis.

Analyzed metals include regulated metals, precious metals, and MMs as follows: antimony ( $\mathrm{Sb}$ ), As, beryllium (Be), Cd, cerium (Ce), chromium $(\mathrm{Cr})$, cobalt (Co), gold (Au), hafnium (Hf), iridium (Ir), lithium (Li), Mo, niobium ( $\mathrm{Nb}$ ), platinum (Pt), palladium (Pd), rhenium ( $\mathrm{Re})$, rhodium $(\mathrm{Rh})$, ruthenium $(\mathrm{Ru})$, Se, silver $(\mathrm{Ag})$, tantalum $(\mathrm{Ta})$, tellurium $(\mathrm{Te}), \mathrm{Ti}$, tungsten $(\mathrm{W})$, vanadium $(\mathrm{V})$, zirconium $(\mathrm{Zr})$, and $\mathrm{Zn}$ (alphabetical order). In the soil samples Ru, Rh, Pd, and V were below the detection limit (1 ppb); thus, they are not presented in the results.

\subsection{Ratio of surface-to-subsurface soil metal concentrations}

To show the vertical profile of all assayed metals at site 1, metal concentrations in soil samples from the $0-30 \mathrm{~cm}$ surface layer were normalized to those in soil samples from the deepest layer of 70-100 cm. The normalization was conducted for each soil core. In the same way, metal concentrations in soil samples from the $0-15 \mathrm{~cm}$ layer were normalized to those in soil samples from the $15-60 \mathrm{~cm}$ layer for site 2 . A normalized ratio greater than one indicates a higher concentration of metals in near-surface soil relative to the deep soil layer, suggesting low potential for vertical mobility. Additionally, to obtain a more detailed vertical profile of the enrichment of each metal via biosolid application, illustrative vertical profiles were constructed for site 1 only because it contained control soil samples as base line for justifying metal accumulation by biosolid application.

\subsection{Characterization of ENMs by TEM}

Biosolids for site 1 and soil samples from both sites were dried and ground to powder in a mortar and pestle. An aliquot of $0.5 \mathrm{~g}$ of each sample was suspended in $5 \mathrm{~mL}$ of DI water. After sonication in a water bath for $1 \mathrm{~h}, 1 \mathrm{~mL}$ of slurry was diluted with $25 \mathrm{~mL}$ of methanol. One or two drops of this suspension were applied to a specimen stub for electron microscopy. High-resolution TEM coupled with EDX (Philips CM200 FEG TEM/STEM, U.S.) was used to characterize the nanoparticles visually and to determine their chemical composition.

\subsection{Statistical analysis}

Statistical analysis was conducted by the software SPSS 11.5 for Windows (SPSS Inc., Chicago, IL). The difference of metal concentrations in each soil depth between site 1 (site 1: 1-1, 1-2, 1-3, and 1-4) and site 1 -control was analyzed with one-way analyses of variance (ANOVA) to test for the effects of biosolid application (i.e., biosolid-amended soil verse control soil). The difference of averaged metal concentrations in each subsite and metal concentrations in each layer of subsites (e.g., metal from 0 to $30 \mathrm{~cm}$ layer in site 1-1 vs. metal from 0 to $30 \mathrm{~cm}$ layer in site 1-2) from a different application rate/time was analyzed by one-way ANOVA as well. The normality of replicate data on metal concentrations was examined when necessary upon Shapiro-Wilk's W test by SPSS $11.5(p>0.05)$.

\section{Results}

\subsection{Metal levels in biosolid-amended soil}

Fig. 1 shows the concentrations of metals in soils, computed as an average overall sample at each site from multiple individual locations, based on averaging 12 samples for each subsite at site 1 (e.g., 12 samples for site 1-1) or 8 samples for each subsite at site 2 (e.g., 8 samples for site 


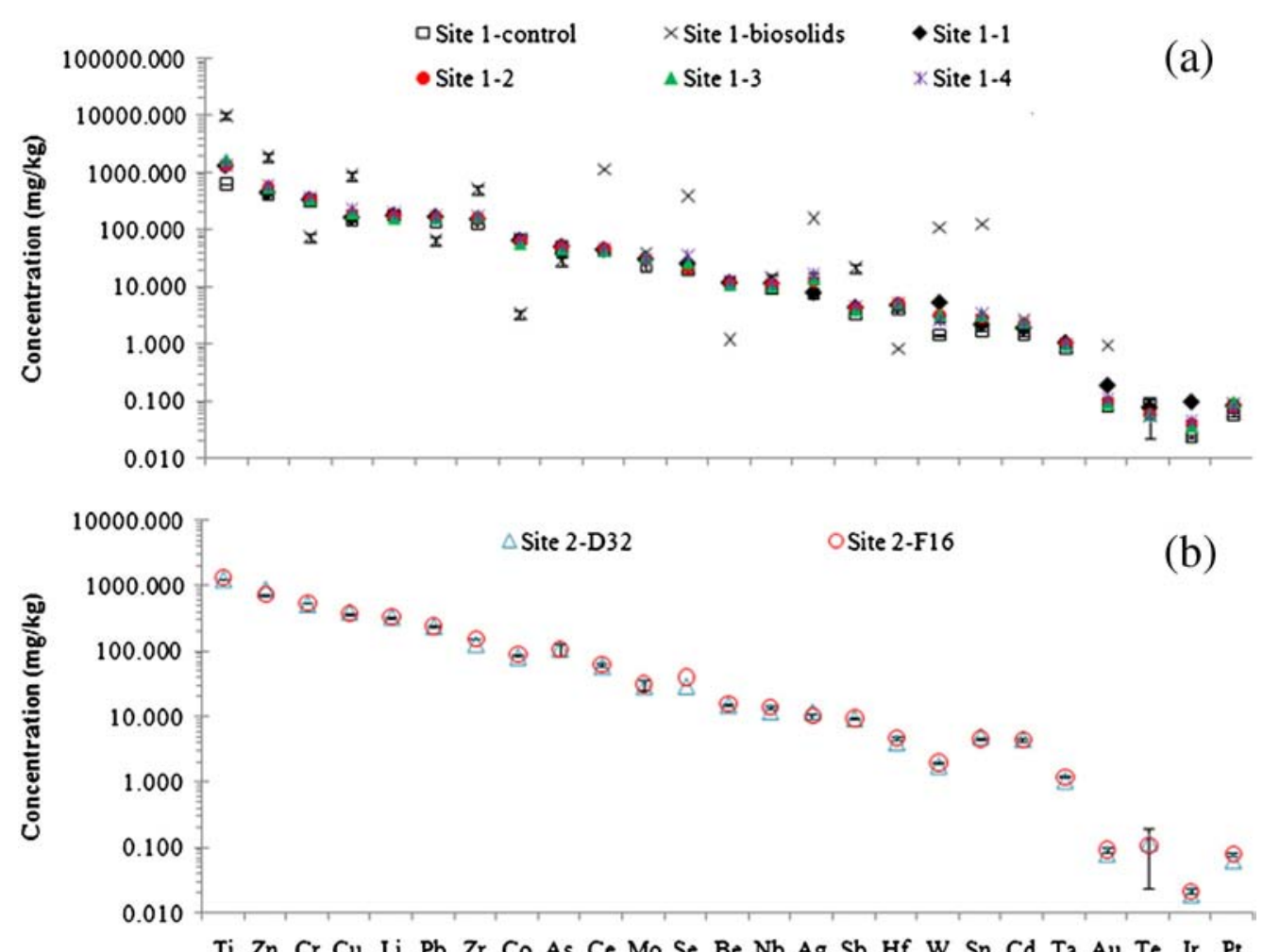

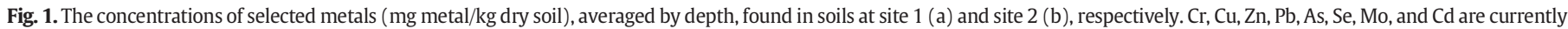
regulated in biosolids. Error bars represent one standard deviation of 8 or 12 replicate samples.

2-D32) regardless of the depth of the soil layers. In terms of this averaged concentration of metals, the higher application rate of biosolids in site 1-3 did not lead to higher metal concentration compared to other subsites in site $1(p>0.05)$. At both sites, the concentrations of $\mathrm{Au}$, Te, Ir, and Pt were $\leq 1 \mathrm{mg} / \mathrm{kg}$, whereas $\mathrm{Cr}, \mathrm{Cu}, \mathrm{Li}, \mathrm{Pb}, \mathrm{Ti}, \mathrm{Zr}$, and $\mathrm{Zn}$ exhibited concentrations $>100 \mathrm{mg} / \mathrm{kg}$. The other elements had intermediate concentrations between 1 and $100 \mathrm{mg} / \mathrm{kg}$. The differences in metal concentrations among control soils, biosolid-amended soils, and biosolids were examined for site 1 . Higher concentrations of $\mathrm{As}, \mathrm{Be}, \mathrm{Cr}$, $\mathrm{Co}, \mathrm{Hf}$, and $\mathrm{Pb}$ in the biosolid-amended soils than in the biosolids were indicative of accumulation. In contrast, the concentrations of $\mathrm{Ag}, \mathrm{Au}$, $\mathrm{Cu}, \mathrm{Ce}, \mathrm{Se}, \mathrm{Sb}, \mathrm{Sn}, \mathrm{Ti}, \mathrm{W}, \mathrm{Zr}$, and $\mathrm{Zn}$ were lower in the biosolid-amended soils than in the biosolids, which indicated a lower original metal concentration in biosolid-amended soils than in biosolids, given the fact that all visible biosolids were removed prior to soil sampling. However, since biosolid samples were just from one year and related metal

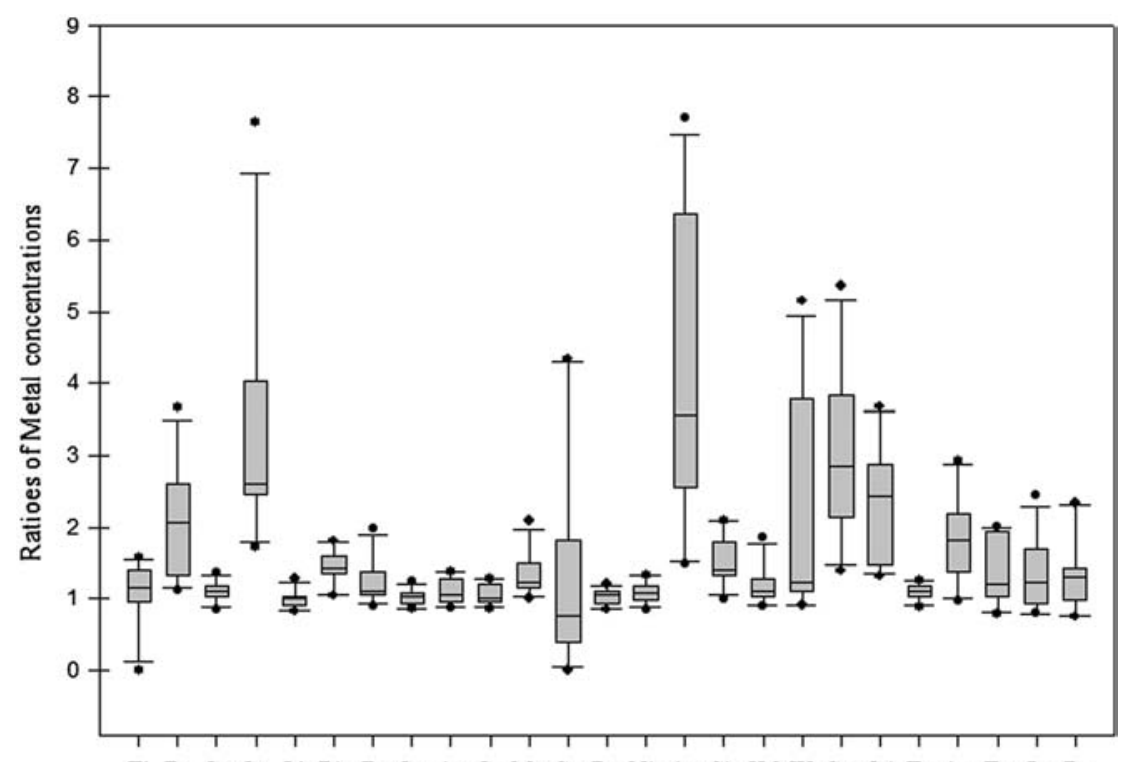

Ti Zn Cr Cu Li Pb Zr Co As Ce Mo Se Be Nb Ag Sb Hf W Sn Cd Ta Au Te Ir Pt

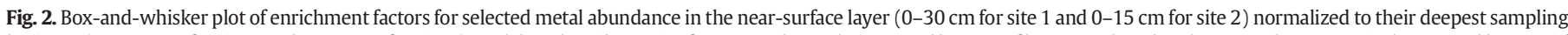

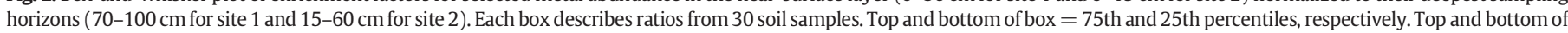
whiskers $=90$ th and 10 th percentiles, respectively. Line across inside of box $=$ median (50th percentile). Points beyond whiskers $=$ outliers . 
concentration fluctuated in past years, the actual accumulation of metals would be ruled out upon comparison of metal concentrations in control soils and biosolid-amended soils.

Soil samples had a similar concentration range to each other within all the subsites of site 2 for the metals present, possibly due to the same application rate. Therefore, Fig. 1 presents metal concentrations for site 2-D32, which had the longest application time (32 years, including application of class B biosolids for only 18 years); site 2-F16, which had the shortest application time ( 8 years). Metal concentrations in the rest of the subsites were within concentration ranges of site 2-F16 to site 2-D32 and thus are not presented here. Since U.S. EPA Part 503 Risk Assessment guidelines for calculating acceptable soil concentrations need background soil concentrations (only available for site 1) (U.S. EPA, 1995), the limit levels of the regulated metals $\mathrm{Cu}, \mathrm{Cd}, \mathrm{Pb}, \mathrm{Se}$, and $\mathrm{Zn}$ were calculated for a $0-100 \mathrm{~cm}$ layer of soils in site 1 , which were $257.9 \mathrm{mg} / \mathrm{kg}$ for $\mathrm{Cu}, 4.4 \mathrm{mg} / \mathrm{kg}$ for Cd, $162.1 \mathrm{mg} / \mathrm{kg}$ for Pb, $28.3 \mathrm{mg} / \mathrm{kg}$ for Se, and $634.2 \mathrm{mg} / \mathrm{kg}$ for $\mathrm{Zn}$ for site 1 . Therefore, concentrations of all the regulated elements in site 1 were below the regulated levels.

\subsection{Metal profiles at different soil depths}

Regulated metals $(\mathrm{Cr}, \mathrm{Cu}, \mathrm{Cd}, \mathrm{Pb}, \mathrm{Zn}$ ) and other metals ( $\mathrm{Ag}, \mathrm{Au}, \mathrm{Hf}$, $\mathrm{Mo}, \mathrm{Nb}, \mathrm{Sn}, \mathrm{Sb}, \mathrm{Ta}, \mathrm{W}$, and $\mathrm{Zr}$ ) were enriched in the surface layer of soils sampled at both site 1 and site 2 (Fig. 2, Table 1). The enrichment of regulated metals at both sites was consistent with previous findings that showed the accumulation of $\mathrm{Cd}, \mathrm{Cr}, \mathrm{Cu}, \mathrm{Ni}, \mathrm{Pb}$, and $\mathrm{Zn}$ in the
0-15 cm depth of soil following sludge application to a different type of soil (Chang et al., 1984). A similar accumulation of Cd, and Cu was found in soils fertilized with poultry litter (Gupta and Charles, 1999). $\mathrm{Au}$ and $\mathrm{Ag}$ are retained in soils under long-term application of biosolids (McBride et al., 1997). To our knowledge, the accumulation in surface soil of some metals analyzed in this test (i.e., Mo, Sn, Sb, Nb, Hf, Ta, W, and $\mathrm{Zr}$ ) has not been addressed in previous literature.

Illustrative vertical profiles were constructed for representative metals at site 1 only, including one regulated metal ( $\mathrm{Zn}$ ), two nonregulated metals potentially associated with ENMs $(\mathrm{Ag}, \mathrm{Ti})$, one MM (Ce), and one PGE (Pt) (Fig. 3). The profiles of the remaining metals assayed at site 1 are listed in the supporting information (Figs. S2-S4). $\mathrm{Ag}$ and $\mathrm{Zn}$ had similar vertical profiles with higher concentrations near the surface $(0-30 \mathrm{~cm})$ than in deeper soil layers $(30-70 \mathrm{~cm}$ and $70-100 \mathrm{~cm}$, Fig. 3). In the near-surface layers, $\mathrm{Ag}$ and $\mathrm{Zn}$ concentrations were significantly higher in biosolid-amended soils than in the control $(p<0.05$, Table S1). In deeper soil layers (30-70 cm and 70-100 cm), there were no significant differences in $\mathrm{Ag}$ and $\mathrm{Zn}$ contents between biosolid-amended soils and control soils $(p>0.05$, specific values are listed in Table S1). Specifically, the concentrations of $\mathrm{Ag}$ in the surface layers of soils were $15 \pm 1.0,27 \pm 0.2,32 \pm 1.6$, and $39 \pm 1.8 \mathrm{mg} / \mathrm{kg}$, at site 1-1 to site 1-4, respectively, which were much higher than the Ag concentrations in the rest of the soil depths, which averaged $5 \mathrm{mg} / \mathrm{kg}$. The concentration of $\mathrm{Zn}$ was in the range of $612-910 \mathrm{mg} / \mathrm{kg}$ in the near surface soil layer of the sampling core, whereas in the other layers and the control the concentrations were approximately $401 \pm 44 \mathrm{mg} / \mathrm{kg}$. The
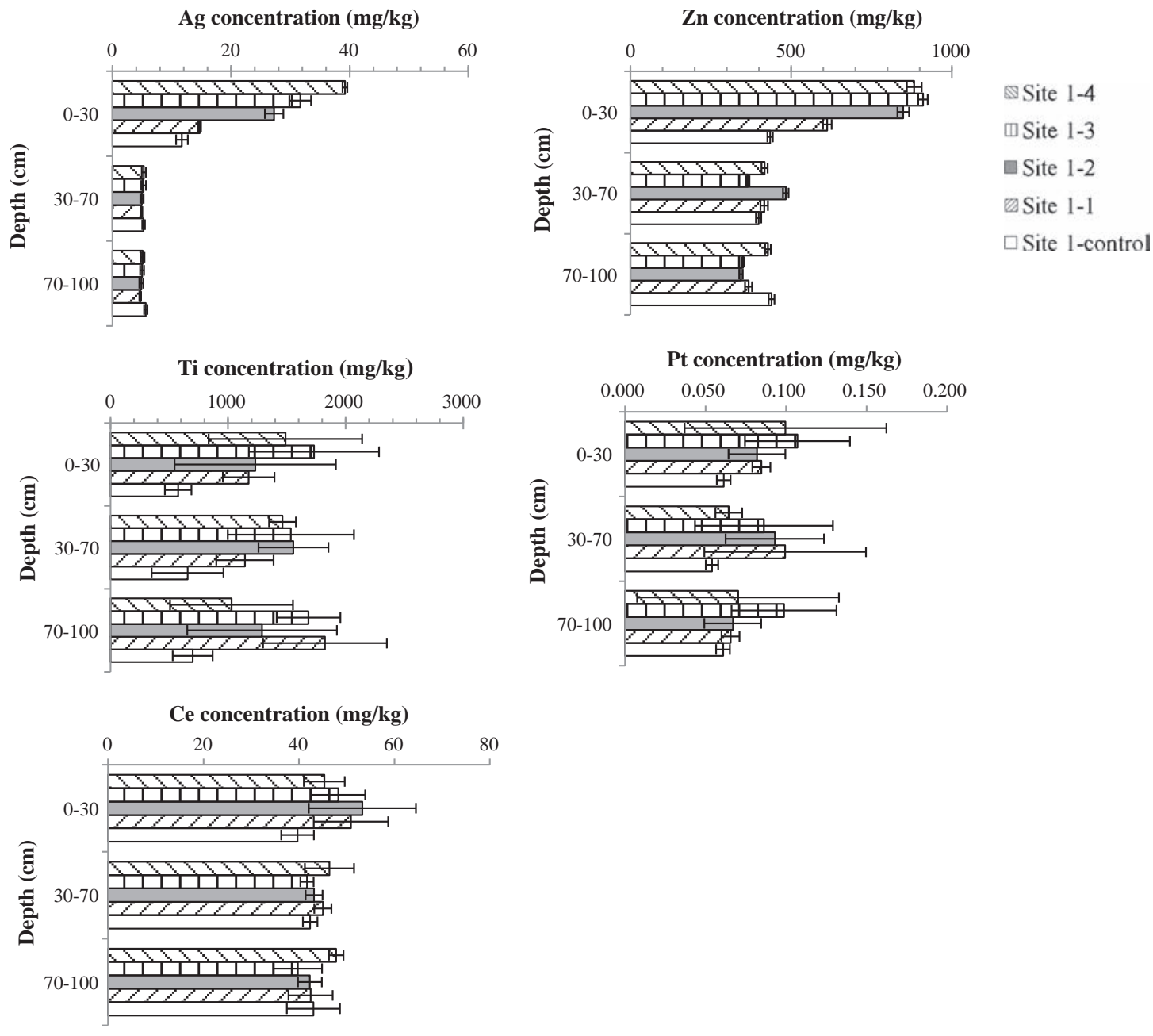

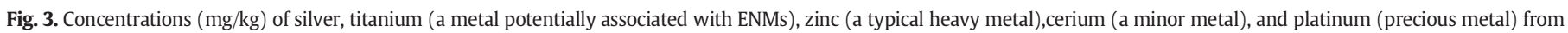
biosolid application plants at three soil depths (below ground surface) at site 1-1, site 1-2, site 1-3, and site 1-4. Error bars represent one standard deviation. 
accumulation of $\mathrm{Zn}$ was observed only in the near-surface layer $(0-30 \mathrm{~cm})$ of biosolid-amended soils. Other metals, including $\mathrm{Cu}, \mathrm{Cd}$, $\mathrm{Mo}, \mathrm{Pb}, \mathrm{Sb}, \mathrm{Sn}$, and $\mathrm{W}$, exhibited profiles similar to those of $\mathrm{Ag}$ and $\mathrm{Zn}$, with higher concentrations in biosolid-amended soils than in the control, a diminishing vertical concentration gradient, and the highest concentrations in near-surface soil (Table S1).

Ti did not exhibit a vertical concentration gradient like that of $\mathrm{Ag}$ or $\mathrm{Zn}$ (Fig. 3), as it had an average concentration of $1428 \pm 253 \mathrm{mg} / \mathrm{kg}$ in biosolid-amended soils across all three depths $(p<0.05)$. In the control soil samples Ti had a background value of $643 \pm 62 \mathrm{mg} / \mathrm{kg}$, which is lower than the typical reported range of 1000 to $9000 \mathrm{mg} / \mathrm{kg}$ in upper continental crust (Kabata-Pendias and Pendias, 2001). The profiles of $\mathrm{Au}, \mathrm{Cr}, \mathrm{Hf}, \mathrm{Nb}$, Ta, and Zr exhibited significant biosolid-application impacts, including higher metal concentrations in biosolid-amended soils than in control soils and similar to Ti profile ( $p$ values are listed in Table S1). Cerium and platinum had similar concentrations in control and biosolid-amended soils. The abundances of As, Be, Co, Ir, Li, Se, and Te did not differ significantly across the soil profile, suggesting that these metals did not accumulate in soils after long-term biosolid application.

\subsection{Presence and characterization of nano-TiO ${ }_{2}$ in biosolids and soils}

Both micron- and nano-size Ti-containing particles were identified in soil samples. Fig. 4 shows Ti-based colloids approximately $50 \mathrm{~nm}$ in diameter in a sample from 0 to $30 \mathrm{~cm}$ layer of site 1-3. From the EDX spectrum (Fig. 4b), the atomic ratio of $\mathrm{O}$ to $\mathrm{Ti}$ is 5.5, which is much higher than the ratio of 2 found in $\mathrm{TiO}_{2}$. The presence of $\mathrm{Al}, \mathrm{Fe}, \mathrm{Ca}$, and $\mathrm{K}$ in the spectrum was also observed. Spectral analysis suggests that

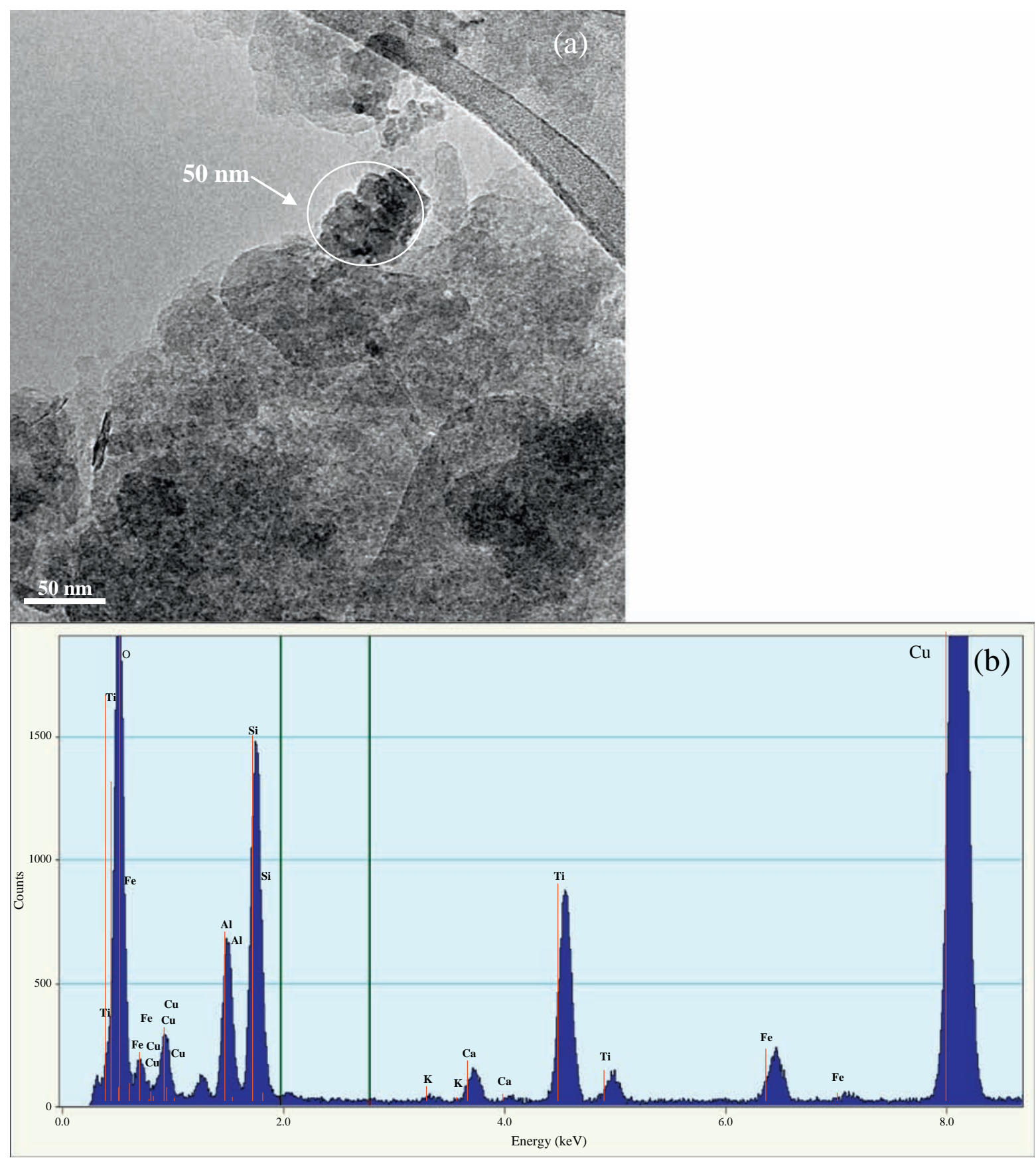

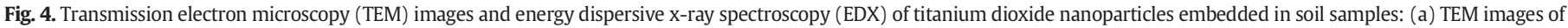
Ti-containing nanoparticles and (b) EDX of Ti-containing nanoparticles. Samples were from 0 to $30 \mathrm{~cm}$ layer of site 1-3. 


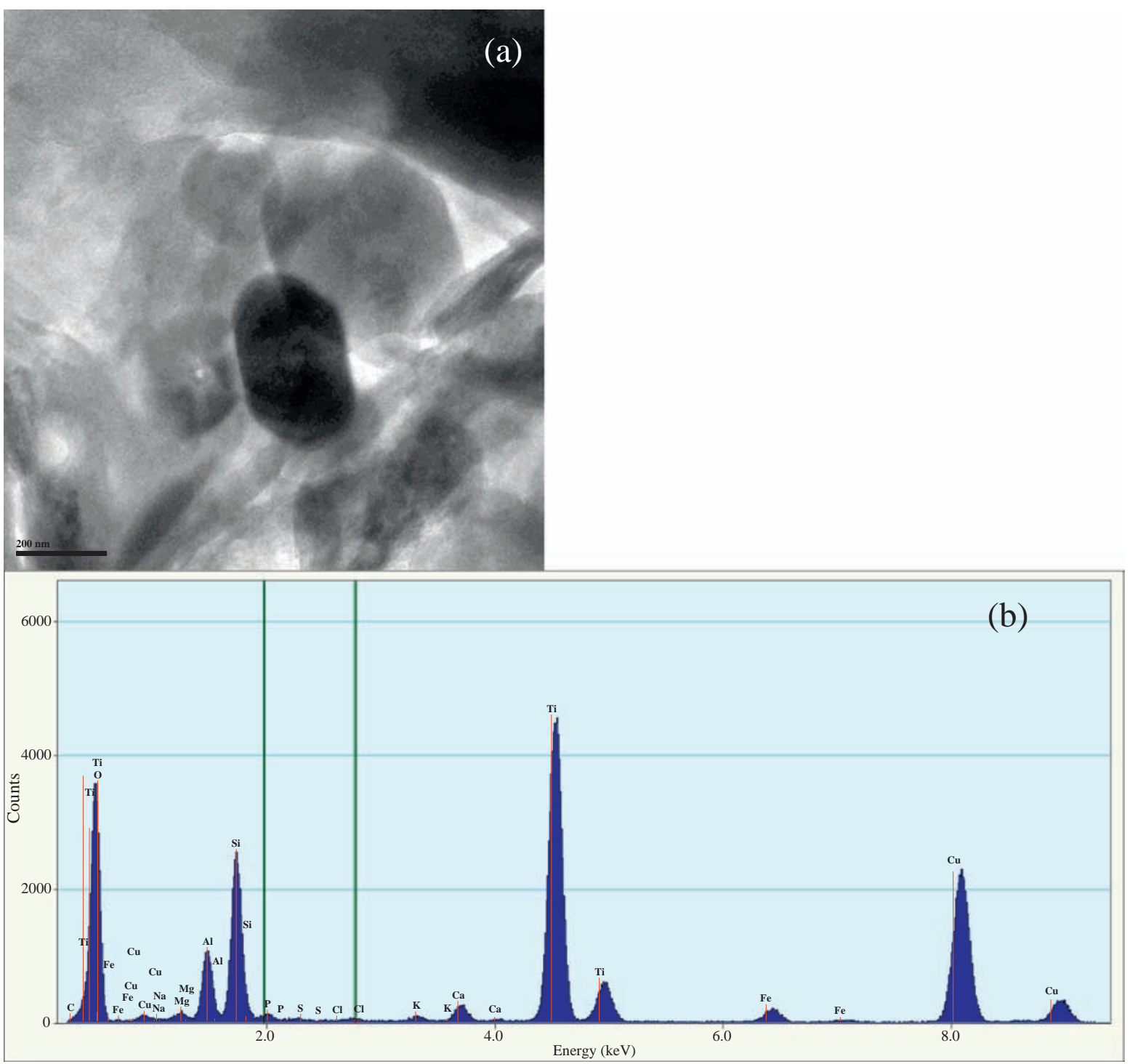

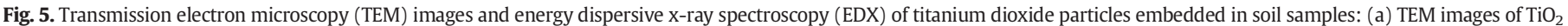
particles and (b) EDX of $\mathrm{TiO}_{2}$ particles. Samples were from 0 to $30 \mathrm{~cm}$ layer of site 1-3.

this Ti-containing nanoparticle is most likely a composite of nano- $\mathrm{TiO}_{2}$ (or titanate) and $\mathrm{Fe} / \mathrm{Al}$ oxide, which was mixed with or embedded in the surrounding organic material, resulting in a higher $\mathrm{O} / \mathrm{Ti}$ ratio.

Micron-size $\mathrm{TiO}_{2}$ particles were frequently observed in TEM images of soil samples in both sites. Fig. 5 shows a $\mathrm{TiO}_{2}$ particle with a diameter of $250 \mathrm{~nm}$ and an atomic ratio of O to Ti of 2.2 in a sample from $0-30 \mathrm{~cm}$ layer of site 1-3. Additional TEM images (Figs. S5-S7) indicate that $\mathrm{TiO}_{2}$ particles were aggregated or attached on the surface of silicate particles. In these TEM images, most of the $\mathrm{TiO}_{2}$ particles present are micron size.

\subsection{Characterization of other metallic particles in soils}

Despite the soils containing up to $16.5 \mathrm{mg} / \mathrm{kg}$ of Ag, particles composed of $\mathrm{Ag}$ (e.g., Ag nanoparticle) were not observed in any samples. It is not surprising that $\mathrm{Ag}$ concentrations in soil were about 100 times less than Ti concentrations. None of the EDX analyses showed any silver response. This does not mean that they are not present, but, given their estimated mass concentration and particle density, the likelihood of locating a nano-silver particle in a biosolid by TEM was less than $0.001 \%$ of that of nano- $\mathrm{TiO}_{2}$ (Westerhoff, 2014).

Significant effort was made (16 TEM samples) to identify other metallic objects that were $<100 \mathrm{~nm}$ in size in soil samples; however, we were unable to detect any other ENMs in these soils. However, large particles containing $\mathrm{Al}, \mathrm{Fe}, \mathrm{Ca}$, and $\mathrm{Si}$ were detected in nearly all the soil samples. Most of them were present as oxide or silica-oxides, and frequently contained multiple elements (e.g., Si, Al, O, C). These particles were often in the $0.5 \mu \mathrm{m}$ to $10 \mu \mathrm{m}$ range in diameter.

\section{Discussion}

\subsection{Accumulation and distribution of metals in biosolid-amended soils}

The enrichment of regulated metals in near-surface soil following biosolid application, relative to deeper soil depths, has been reported in various types of soils (Chang et al., 1984; McBride et al., 1997). Our data showed that at site 1 all the regulated metals except As and Se have similar vertical distribution profiles with a decreasing gradient from near-surface soils $(0-30 \mathrm{~cm})$ to deeper soils $(30-70 \mathrm{~cm}$, $70-100 \mathrm{~cm}$ ) (Fig. 3). Soils with high clay content could preferentially retain regulated metals, which may explain the accumulation of regulated metals in surface soils (Cabrera et al., 1999; Han et al., 2000). Anions such as chloride and sulfide, which can complex or associate with metal ions, reduced the metal solubility and mobility (Singh and Agrawal, 2008). Metals that could form complexes or precipitates with 
anions were more resistant to leaching and thus were retained in the near-surface layer after entering into the soils. For instance, $\mathrm{Ag}$ ions can form precipitates with several anions (e.g. $\mathrm{S}^{2-}, \mathrm{CI}^{-}, \mathrm{OH}^{-}$) with low solubility (Stumm and Morgan, 1996), which might lead to the lower mobility of silver and thus showed higher concentration in surface soils than in deeper soils.

At site 1, comparison of control soils and biosolid-amended soils indicated that $\mathrm{Ce}, \mathrm{Pt}$, and many other metals (As, Be, Co, Ir, Li, Se, and $\mathrm{Te}$ ) did not accumulate in biosolid-amended soils. The measured $\mathrm{Ce}$ concentration in soils was ( $45 \pm 4 \mathrm{mg} / \mathrm{L}$ ) consistent with values previously reported by USGS, namely, an average Ce concentration of $75 \mathrm{mg} / \mathrm{kg}$ and a maximum concentration of $300 \mathrm{mg} / \mathrm{kg}$, based on a survey of soil samples from more than 21 US states (Shacklette and Boerngen, 1984). Because water can easily desorb Ce from soils (Wen et al., 2002), the even distribution of Ce in soils could be expected in an area with a mean annual precipitation of $817 \mathrm{~mm}$ though other reason could not be excluded (e.g. the historical concentrations of Ce in biosolids might be extremely low). Concentrations of other elements, including As, Be, Co, Ir, Li, Se, Te, and Ti did not exhibit a metal accumulation to biosolid application; these elements may be more mobile in soils. Elements including $\mathrm{Au}, \mathrm{Cr}, \mathrm{Hf}, \mathrm{Nb}, \mathrm{Ta}, \mathrm{Ti}$, and $\mathrm{Zr}$ had higher concentrations in the near-surface layer $(0-30 \mathrm{~cm})$ in biosolid-amended soils than in control soils.

The length of the biosolid application period and the application rate contribute to the final content of some metals in soils. The long-term ( $20+$ years) application field at site 1-4 had the highest $\mathrm{Cu}$ concentration in surface soil. Sn concentrations were statistically the same at site 1-4 and site 1-3 ( $p>0.05)$ but higher than at site 1-1 and site $1-2$, which had lower biosolid application rates. Metals that behave more similarly to Ti did not exhibit this trend, likely due to their higher mobility in soils. Therefore, the biosolid application rate and duration may have more impact on the accumulation of metals with lower mobility in soils than of metals with higher mobility, particularly in areas like those assayed where erosion rates are low. Further research focused on the exact mechanisms of metal transport in biosolid-amended soils is needed, which would discuss more about the effects of climatology, hydrology, and solubility/partitioning of metals in soils.

\subsection{The ratio of nano $\mathrm{TiO}_{2}$ relative to the bulk $\mathrm{TiO}_{2}$ in biosolid-amended} soils

The ratio of nano- $\mathrm{TiO}_{2}$ particles relative to the bulk $\mathrm{TiO}_{2}$ (total amount) could be estimated upon determined Ti concentration and published nano- $\mathrm{TiO}_{2}$ concentration in biosolid-amended soils. Assuming that all Ti analyzed was in the form of $\mathrm{TiO}_{2}$ though the existence of other Ti containing salts/materials was not excluded, the concentrations of $\mathrm{TiO}_{2}$ ranged from 91 to $230 \mathrm{mg} / \mathrm{kg}$ per year at site $1\left(\mathrm{TiO}_{2}\right.$ concentrations divided by application years). Following the estimated concentration of nano- $\mathrm{TiO}_{2}$ in biosolid-amended soils is $170 \mu \mathrm{g} / \mathrm{kg}$ per year (Gottschalk et al., 2009), the nano- $\mathrm{TiO}_{2}$ in our analyzed samples accounts for roughly $0.07 \%-0.2 \%$ of the total Ti. Therefore, only one Ti-containing nanoparticle was observed in biosolid-amended soils (Fig. 4), whereas most of the Ti-containing particles were of micron size. Whether this particle came from an anthropogenic source or occurred naturally in soils is not clear; more research is needed to track the sources of nanomaterials in biosolid treatment facilities.

\section{Conclusions}

The land application of biosolids poses potential ecotoxicity concerns with regard to enriched metals. A survey of metal concentrations in Texas biosolid treatment facilities indicated that the land application of biosolids may lead to the accumulation of regulated metals (e.g., $\mathrm{Cr}$ ) and ENM-related metals (e.g., Ti). Specifically, regulated metals ( $\mathrm{Cr}$, $\mathrm{Cu}, \mathrm{Cd}, \mathrm{Pb}, \mathrm{Zn}$ ), plus various other metals (Ag, Au, Hf, Mo, Nb, Sn, Sb, $\mathrm{Ta}, \mathrm{W}$, and $\mathrm{Zr}$ ) accumulated in near-surface soils. This research provides the first baseline for potential nano-metal forms in soils. Profiles of major ENM-related metals ( $\mathrm{Ag}$, $\mathrm{Ti}$, and $\mathrm{Zn}$ ) reveal their accumulation and indicate their low mobility after entering the soils. A major ENM, a Ti-containing nanomaterial (approximately $50 \mathrm{~nm}$ in diameter, and sometimes $\sim 250 \mathrm{~nm}$ ), was identified by TEM in a soil sample. Therefore, ecotoxicity tests need to be conducted on biosolid-amended soils in situ as a result of the regulated metal accumulation and the existence of ENMs.

\section{Conflict of interest}

The authors declare no potential conflict of interest including any financial, personal or other relationships with other people or organizations within three years of beginning the submitted work that could inappropriately influence, or be perceived to influence, the work.

\section{Acknowledgments}

This study was funded by the Water Environment Research Foundation (WERF) and USEPA (RD831713 and RD833322). Funding for sample collection at field sites was provided by Agriculture and Food Research Initiative Competitive Grant no. 2008-35101-04440 to JGA from the USDA National Institute of Food and Agriculture. Any opinions, findings, and conclusions or recommendations expressed in this material are those of the author(s) and do not necessarily reflect the views of the WERF, USEPA, and USDA. We thank Sungyun Lee and Xiangyu $\mathrm{Bi}$ for their help in the analysis of metal contents by ICP-MS.

\section{Appendix A. Supplementary data}

Additional details covered by this paper 419 include additional TEM micrographs of TiO2 420 particles in soils and vertical profiles of metals at different depths of the soil samples from 421 site 1 . Supplementary data to this article can be found online at http://dx.doi.org/10.1016/j. scitotenv.2014.03.122.

\section{References}

APHA, AWWA, WEF. Standard methods for the examination of water and wastewater; 2005.

Benn TM, Westerhoff P. Nanoparticle silver released into water from commercially available sock fabrics. Environ Sci Technol 2008;42(11):4133-9.

Cabrera F, Clemente L, Diaz Barrientos E, Lopez R, Murillo JM. Heavy metal pollution of soils affected by the Guadiamar toxic flood. Sci Total Environ 1999;242(1-3):117-29.

Chang AC, Warneke JE, Page AL, Lund LJ. Accumulation of heavy metals in sewage sludgetreated soils1. J Environ Qual 1984;13(1):87-91.

Choi JE, Kim S, Ahn JH, Youn P, Kang JS, Park K, et al. Induction of oxidative stress and apoptosis by silver nanoparticles in the liver of adult zebrafish. Aquat Toxicol 2010; 100(2):151-9.

De la Rosa G, Lopez-Moreno ML, Hernandez-Viezcas J, Montes MO, Peralta-Videa JR, Gardea-Torresdey JL. Toxicity and biotransformation of $\mathrm{ZnO}$ nanoparticles in the desert plants Prosopis juliflora-velutina, Salsola tragus and Parkinsonia florida. Int J Nanotechnol 2011;8(6-7):492-506.

Franzen DW, Cihacek LJ. Soil sampling as a basis for fertilizer application. NDSU extension service. Fargo, ND: North Dakota State University; 1998.

Ge Y, Schimel JP, Holden PA. Evidence for negative effects of TiO2 and ZnO nanoparticles on soil bacterial communities. Environ Sci Technol 2011;45(4):1659-64.

Glover RD, Miller JM, Hutchison JE. Generation of metal nanoparticles from silver and copper objects: nanoparticle dynamics on surfaces and potential sources of nanoparticles in the environment. ACS Nano 2011;5(11):8950-7.

Gottschalk F, Sonderer T, Scholz RW, Nowack B. Modeled environmental concentrations of engineered nanomaterials $\left(\mathrm{TiO}_{2}, \mathrm{ZnO}, \mathrm{Ag}, \mathrm{CNT}\right.$, Fullerenes) for different regions. Environ Sci Technol 2009;43(24):9216-22.

Graedel TE, Van Der Voet E. Linkages of sustainability. Mit Press; 2010.

Gupta G, Charles S. Trace elements in soils fertilized with poultry litter. Poult Sci 1999; 78(12):1695-8.

Han FX, Kingery WL, Selim HM, Gerard PD. Accumulation of heavy metals in a long-term poultry waste-amended soil. Soil Sci 2000;165(3):260-8.

Hue NV, Ranjith S. Sewage sludges in Hawaii: chemical composition and reactions with soils and plants. Water Air Soil Pollut 1994;72(1-4):265-83.

Illera V, Walter I, Souza P, Cala V. Short-term effects of biosolid and municipal solid waste applications on heavy metals distribution in a degraded soil under a semi-arid environment. Sci Total Environ 2000;255(1-2):29-44. 
Jin VL, Johnson M-VV, Haney RL, Arnold JG. Potential carbon and nitrogen mineralization in soils from a perennial forage production system amended with class B biosolids. Agr Ecosyst Environ 2011;141(3-4):461-5.

Jorg S, Eckhardt J-D, Berner ZA, Stuben D. Time-dependent increase of traffic-emitted platinum-group elements (PGE) in different environmental compartments. Environ Sci Technol 1999;33(18):3166-70.

Judy JD, Unrine JM, Rao W, Bertsch PM. Bioaccumulation of gold nanomaterials by Manduca sexta through dietary uptake of surface contaminated plant tissue. Environ Sci Technol 2012;46(22):12672-8.

Kabata-Pendias A, Pendias H. Trace elements in soils and plants. 3rd ed. Taylor \& Francis Group; 2001.

Kim B, Murayama M, Colman BP, Hochella MF. Characterization and environmental implications of nano- and larger $\mathrm{TiO}_{2}$ particles in sewage sludge, and soils amended with sewage sludge. J Environ Monit 2012;14(4):1129-37.

McBride MB, Richards BK, Steenhuis T, Russo JJ, Sauve S. Mobility and solubility of toxic metals and nutrients in soil fifteen years after sludge application. Soil Sci 1997; 162(7):487-500.

Nowack B, Bucheli TD. Occurrence, behavior and effects of nanoparticles in the environment. Environ Pollut 2007;150(1):5-22.

Shacklette HT, Boerngen JG. Element concentrations in soils and other surficial material of the conterminous United States. U S Geol Surv Prof Pap. Washington: United States Government Printing Office; 1984.

Singh RP, Agrawal M. Potential benefits and risks of land application of sewage sludge. Waste Manag 2008;28(2):347-58.

Sloan JJ, Dowdy RH, Dolan MS, Linden DR. Long-term effects of biosolids applications on heavy metal bioavailability in agricultural soils. J Environ Qual 1997;26(4):966-74.
Smith SR. A critical review of the bioavailability and impacts of heavy metals in municipal solid waste composts compared to sewage sludge. Environ Int 2009;35(1):142-56.

Stumm W, Morgan JJ. Aquatic chemistry: chemical equilibria and rates in natural waters. New York: John Wiley \& Sons, Inc.; 1996.

Tourinho PS, van Gestel CAM, Lofts S, Svendsen C, Soares AMVM, Loureiro S. Metal-based nanoparticles in soil: fate, behavior, and effects on soil invertebrates. Environ Toxicol Chem 2012;31(8):1679-92.

U.S. EPA. A guide to the biosolids risk assessments for the EPA Part 503 rule. Washington, DC: U.S. EPA, Office of Wastewater Management; 1995.

U.S. EPA. Biosolids generation, use, and disposal in the United States. Washington DC: U.S. Environmental Protection Agency; 1999.

U.S. EPA. Nanomaterial case studies: nanoscale titanium dioxide in water treatment and in topical sunscreen (final). Washington, DC: U.S. Environmental Protection Agency; 2010.

USDA-NRCS. National soil survey characterization data, soil survey staff, soil survey laboratory. Lincoln, NE: National Soil Survey Center, USDA-NRCS; 2007.

Wen B, Shan X-q, Lin J-m, Tang G-g, Bai N-b, Yuan D-a. Desorption kinetics of yttrium, lanthanum, and cerium from soils. Soil Sci Soc Am J 2002;66(4):1198-206.

Westerhoff P. Fate of engineered nanomaterials in wastewater biosolids, land application, and incineration. Water Environment Research Foundation; 2014

Yang Y, Chen Q, Wall JD, Hu Z. Potential nanosilver impact on anaerobic digestion at moderate silver concentrations. Water Res 2012a;46(4):1176-84.

Yang Y, Xu M, Wall JD, Hu Z. Nanosilver impact on methanogenesis and biogas production from municipal solid waste. Waste Manag 2012b;32(5):816-25.

Yang Y, Zhang C, Hu Z. Impact of metallic and metal oxide nanoparticles on wastewater treatment and anaerobic digestion. Environ Sci: Processes Impacts 2013;15: 39-48. 


\section{Metal and Nanoparticle Occurrence in Biosolid Amended Soils}

\section{Authors:}

Yu Yang ${ }^{a^{*}}$, Yifei Wang ${ }^{\mathrm{a}}$, Paul Westerhoff ${ }^{\mathrm{a}}$, Kiril Hristovski ${ }^{\mathrm{b}}$, Virginia L. Jin ${ }^{\mathrm{c}}$, Mari-Vaughn V.

Johnson $^{\mathrm{d}}$, Jeffrey G.Arnold ${ }^{\mathrm{e}}$

\section{Affiliations:}

${ }^{\mathrm{a}}$ School of Sustainable Engineering and the Built Environment, Arizona State University, Tempe, AZ 85287-5306, United States

${ }^{\mathrm{b}}$ College of Technology and Innovation, Arizona State University at the Polytechnic Campus, Mesa, AZ 85212,United States

${ }^{c}$ USDA - Agricultural Research Service, University of Nebraska-Lincoln, East Campus, Lincoln, NE 68583-0937, United States

${ }^{\mathrm{d} U S D A}$ - Natural Resources Conservation Service, Grassland, Soil, and Water Research Laboratory, Temple, TX 76502, United States

${ }^{\mathrm{e} U S D A}$ - Agricultural Research Service, Grassland, Soil, and Water Research Laboratory, Temple, TX 76502, United States

\section{*Corresponding Author and Address:}

Yu Yang ${ }^{a^{*}}$,School of Sustainable Engineering and the Built Environment, Arizona State University, Tempe, AZ 85287-5306, United States

Phone: 480 727-2913; e-mail: yu.yang.2@asu.edu.

Original Submission of Supporting Information

No.of Supporting Pages: 9

No.of Supporting Tables: 1

No. of SupportingFigures: 7 
Table S1. The significant difference ( $\mathrm{p}$ value) in metal content between biosolids-amended soils and control soil at site 1

\begin{tabular}{|c|c|c|c|c|c|c|c|c|c|c|c|c|}
\hline \multirow[b]{2}{*}{ Metals } & \multicolumn{3}{|c|}{ Site 1-1 } & \multicolumn{3}{|c|}{ Site 1-2 } & \multicolumn{3}{|c|}{ Site 1-3 } & \multicolumn{3}{|c|}{ Site 1-4 } \\
\hline & $\begin{array}{l}0-30 \\
\mathrm{~cm} \\
\end{array}$ & $\begin{array}{l}30-70 \\
\mathrm{~cm}\end{array}$ & $\begin{array}{l}70-100 \\
\mathrm{~cm}\end{array}$ & $\begin{array}{l}0-30 \\
\mathrm{~cm} \\
\end{array}$ & $\begin{array}{l}30-70 \\
\mathrm{~cm}\end{array}$ & $\begin{array}{l}70-100 \\
\mathrm{~cm}\end{array}$ & $\begin{array}{l}0-30 \\
\mathrm{~cm} \\
\end{array}$ & $\begin{array}{l}30-70 \\
\mathrm{~cm}\end{array}$ & $\begin{array}{l}70-100 \\
\mathrm{~cm}\end{array}$ & $\begin{array}{l}0-30 \\
\mathrm{~cm} \\
\end{array}$ & $\begin{array}{l}30-70 \\
\mathrm{~cm}\end{array}$ & $\begin{array}{l}70-100 \\
\mathrm{~cm}\end{array}$ \\
\hline $\mathrm{Cr}$ & 0.004 & 0.005 & 0.617 & 0.088 & 0.173 & 0.880 & 0.052 & 0.567 & 0.959 & 0.015 & 0.177 & 0.032 \\
\hline $\mathrm{Cu}$ & 0.000 & 0.099 & 0.083 & 0.034 & 0.880 & 0.247 & 0.000 & 0.129 & 0.040 & 0.000 & 0.258 & 0.628 \\
\hline $\mathrm{Zn}$ & 0.032 & 0.353 & 0.140 & 0.052 & 0.307 & 0.354 & 0.019 & 0.126 & 0.094 & 0.012 & 0.613 & 0.885 \\
\hline $\mathrm{Pb}$ & 0.071 & 0.057 & 0.326 & 0.008 & 0.065 & 0.479 & 0.001 & 0.636 & 0.221 & 0.001 & 0.264 & 0.889 \\
\hline As & 0.008 & 0.079 & 0.044 & 0.001 & 0.125 & 0.008 & 0.559 & 0.322 & 0.178 & 0.341 & 0.194 & 0.027 \\
\hline $\mathrm{Se}$ & 0.838 & 0.085 & 0.480 & 0.498 & 0.084 & 0.908 & 0.632 & 0.298 & 0.448 & 0.829 & 0.081 & 0.121 \\
\hline Mo & 0.000 & 0.024 & 0.141 & 0.003 & 0.001 & 0.211 & 0.000 & 0.000 & 0.135 & 0.000 & 0.003 & 0.039 \\
\hline $\mathrm{Cd}$ & 0.006 & 0.416 & 0.212 & 0.011 & 0.410 & 0.436 & 0.000 & 0.774 & 0.113 & 0.000 & 0.458 & 0.351 \\
\hline $\mathrm{Li}$ & 0.383 & 0.016 & 0.096 & 0.028 & 0.108 & 0.683 & 0.003 & 0.036 & 0.836 & 0.043 & 0.410 & 0.004 \\
\hline $\mathrm{Zr}$ & 0.016 & 0.004 & 0.095 & 0.003 & 0.005 & 0.154 & 0.000 & 0.001 & 0.097 & 0.001 & 0.006 & 0.010 \\
\hline $\mathrm{Nb}$ & 0.003 & 0.003 & 0.019 & & & & & & & & 0.033 & 0.005 \\
\hline Co & 0.731 & 0.744 & 0.694 & 0.015 & 0.063 & 0.614 & 0.002 & 0.011 & 0.319 & 0.099 & 0.787 & 0.061 \\
\hline $\mathrm{Be}$ & 0.254 & 0.800 & 0.630 & 0.408 & 0.213 & 0.438 & 0.030 & 0.265 & 0.551 & 0.441 & 0.918 & 0.126 \\
\hline $\mathrm{Ce}$ & 0.137 & 0.170 & 0.480 & 0.136 & 0.581 & 0.706 & 0.164 & 0.787 & 0.990 & 0.437 & 0.255 & 0.062 \\
\hline Sn & 0.000 & 0.046 & 0.156 & 0.019 & 0.194 & & 0.000 & 0.195 & 0.109 & 0.000 & 0.180 & 0.439 \\
\hline $\mathrm{Sb}$ & 0.011 & 0.004 & 0.093 & 0.023 & 0.014 & 0.882 & 0.000 & 0.328 & 0.618 & 0.000 & 0.052 & 0.052 \\
\hline $\mathrm{Hf}$ & 0.020 & 0.002 & 0.151 & 0.011 & 0.004 & 0.103 & 0.000 & 0.000 & 0.082 & 0.006 & 0.008 & 0.005 \\
\hline $\mathrm{Ta}$ & 0.002 & 0.028 & 0.005 & 0.036 & 0.019 & 0.251 & 0.003 & 0.176 & 0.193 & 0.032 & 0.046 & 0.004 \\
\hline W & 0.000 & 0.007 & 0.256 & 0.007 & 0.003 & 0.468 & 0.000 & 0.264 & 0.516 & 0.000 & 0.156 & 0.332 \\
\hline $\mathrm{Te}$ & 0.000 & 0.000 & 0.014 & 0.009 & 0.001 & 0.000 & 0.000 & 0.010 & 0.000 & 0.000 & 0.000 & 0.007 \\
\hline Ir & 0.001 & 0.094 & 0.113 & 0.064 & 0.192 & 0.010 & 0.222 & 0.139 & 0.035 & 0.098 & 0.095 & 0.178 \\
\hline $\mathrm{Pt}$ & 0.004 & 0.186 & 0.509 & 0.063 & 0.093 & 0.443 & 0.031 & 0.191 & 0.251 & 0.263 & 0.104 & 0.086 \\
\hline $\mathrm{Au}$ & 0.000 & 0.591 & 0.139 & 0.000 & 0.472 & 0.068 & 0.003 & 0.559 & 0.400 & 0.003 & 0.831 & 0.229 \\
\hline $\mathrm{Ag}$ & 0.001 & 0.351 & 0.016 & 0.010 & 0.574 & 0.243 & 0.000 & 0.982 & 0.022 & 0.001 & 0.903 & 0.046 \\
\hline $\mathrm{Ti}$ & 0.004 & 0.047 & 0.005 & 0.108 & 0.001 & 0.123 & 0.003 & 0.040 & 0.086 & 0.030 & 0.040 & 0.275 \\
\hline
\end{tabular}




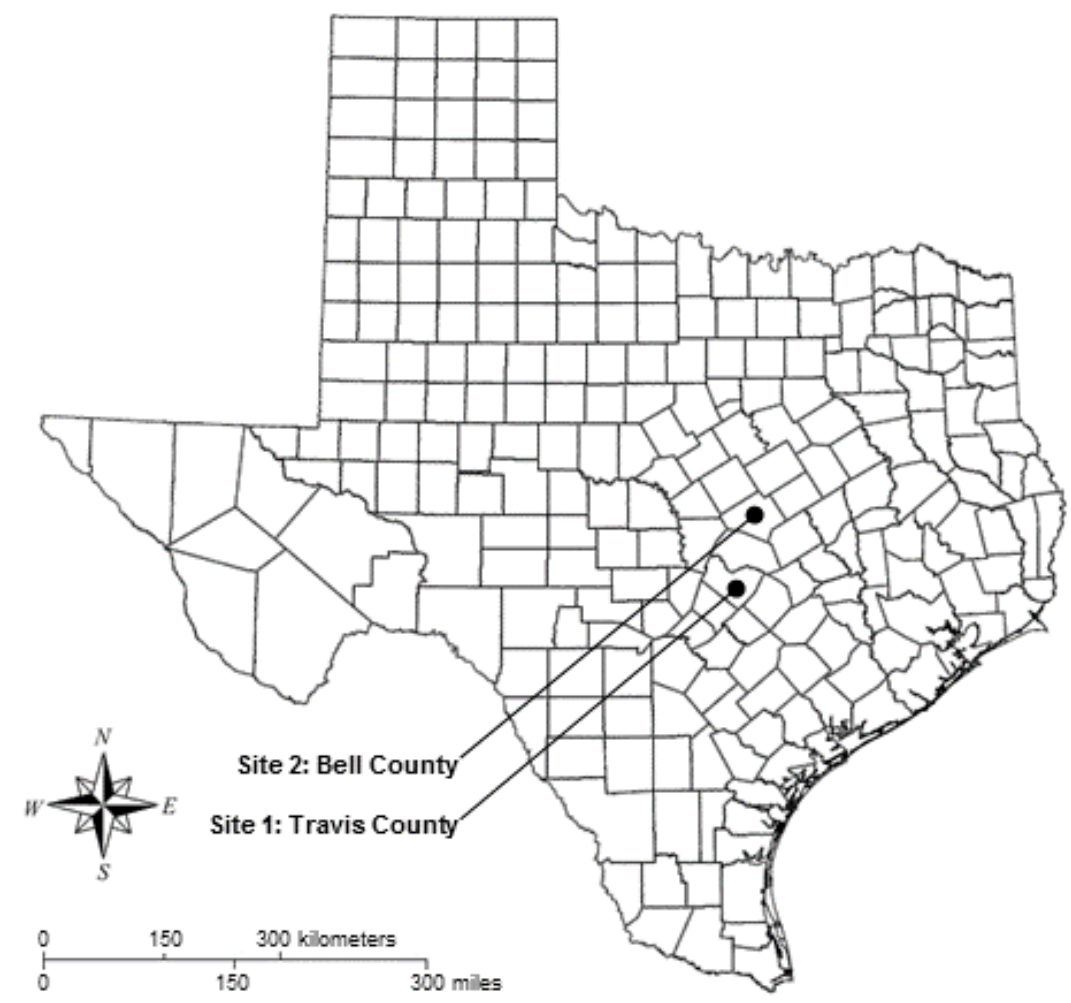

Fig.S1. Study site locations in Texas (map source: Texas Parks and Wildlife). 

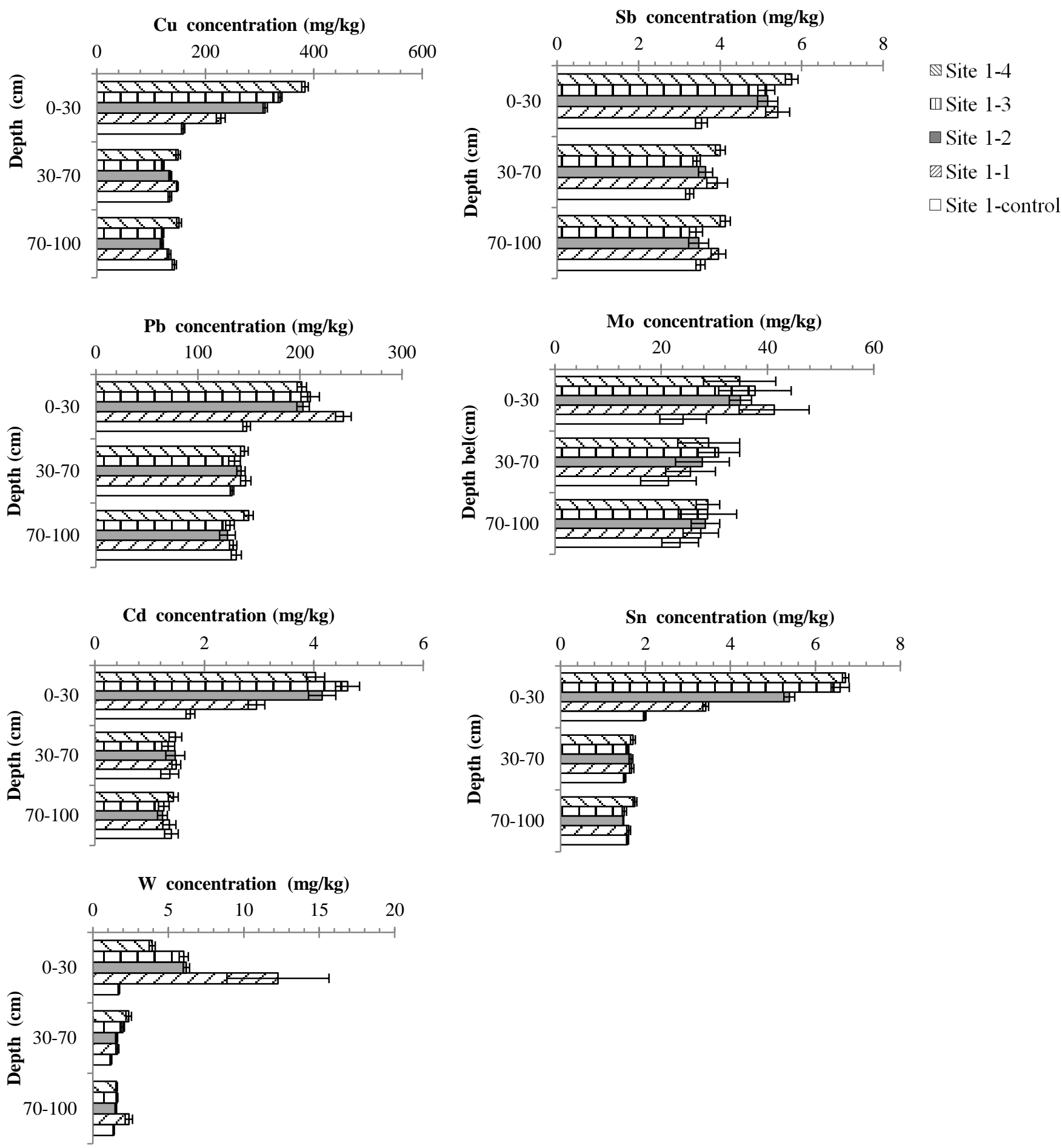

Fig. S2.Concentrations $(\mathrm{mg} / \mathrm{kg})$ of metals $(\mathrm{Cu}, \mathrm{Sb}, \mathrm{Pb}, \mathrm{Mo}, \mathrm{Cd}, \mathrm{Sn}$, and $\mathrm{W})$ at site 1-1, site 1-2, site 1-3, and site 1-4 at three depths of soils amended by biosolids. Error bars represent one standard deviation of measured samples. The metals exhibit trends similar to those of $\mathrm{Ag}$ and $\mathrm{Zn}$. 

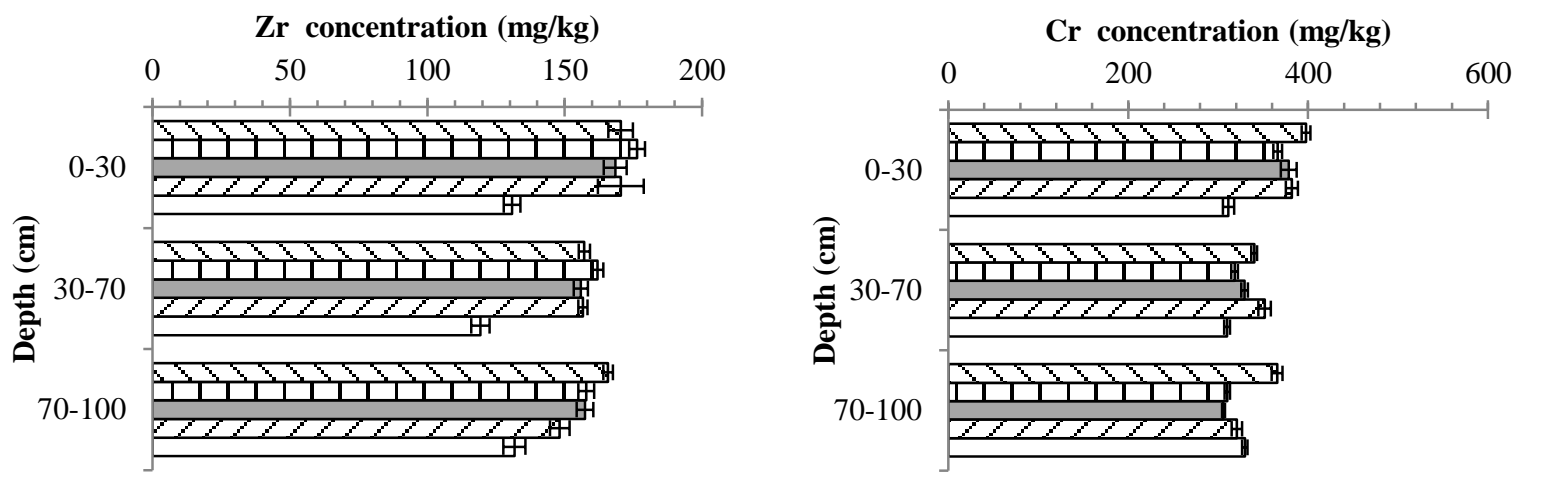

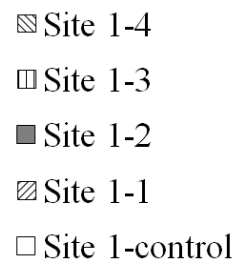
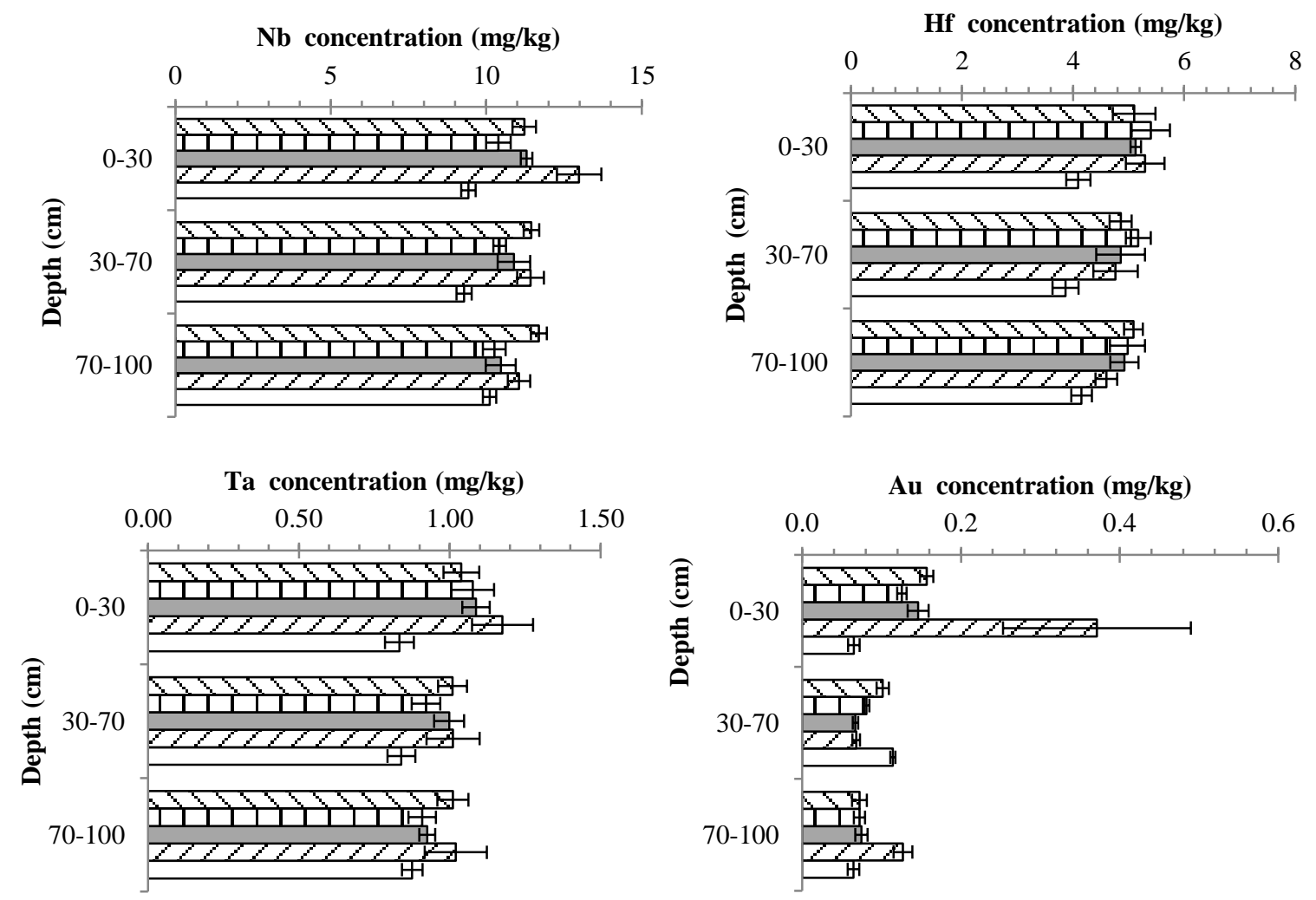

Fig. S3.Concentrations $(\mathrm{mg} / \mathrm{kg}$ ) of metals $(\mathrm{Zr}, \mathrm{Cr}, \mathrm{Nb}, \mathrm{Hf}, \mathrm{Ta}$, and $\mathrm{Au}$ ) at site 1-1, site 1-2, site 1-3, and site 1-4 at three depths of soils amended by biosolids. Error bars represent one standard deviation of measured samples. The metals exhibit trends similar to that of Ti. 

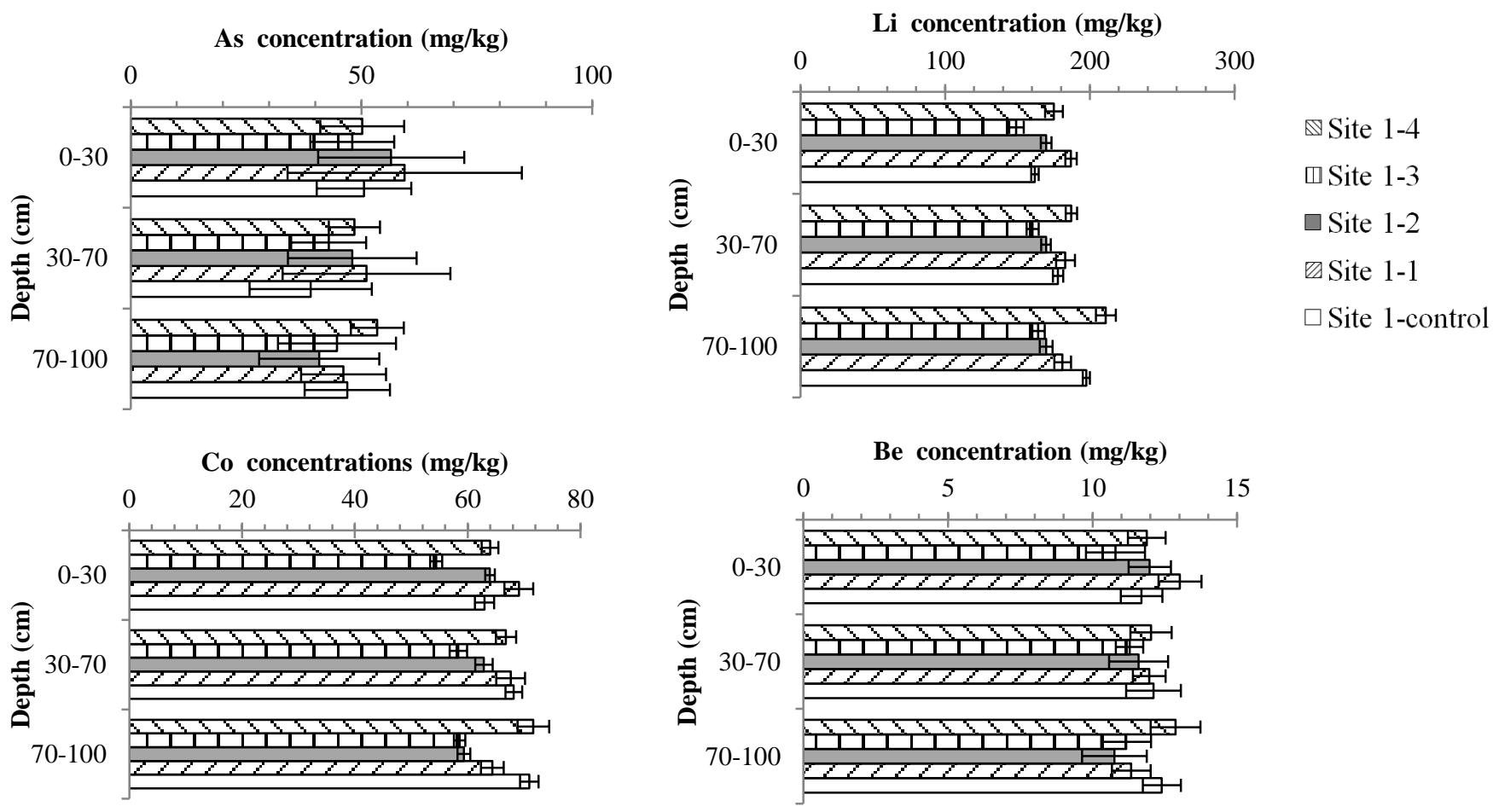

Se concentrations $(\mathrm{mg} / \mathrm{kg})$
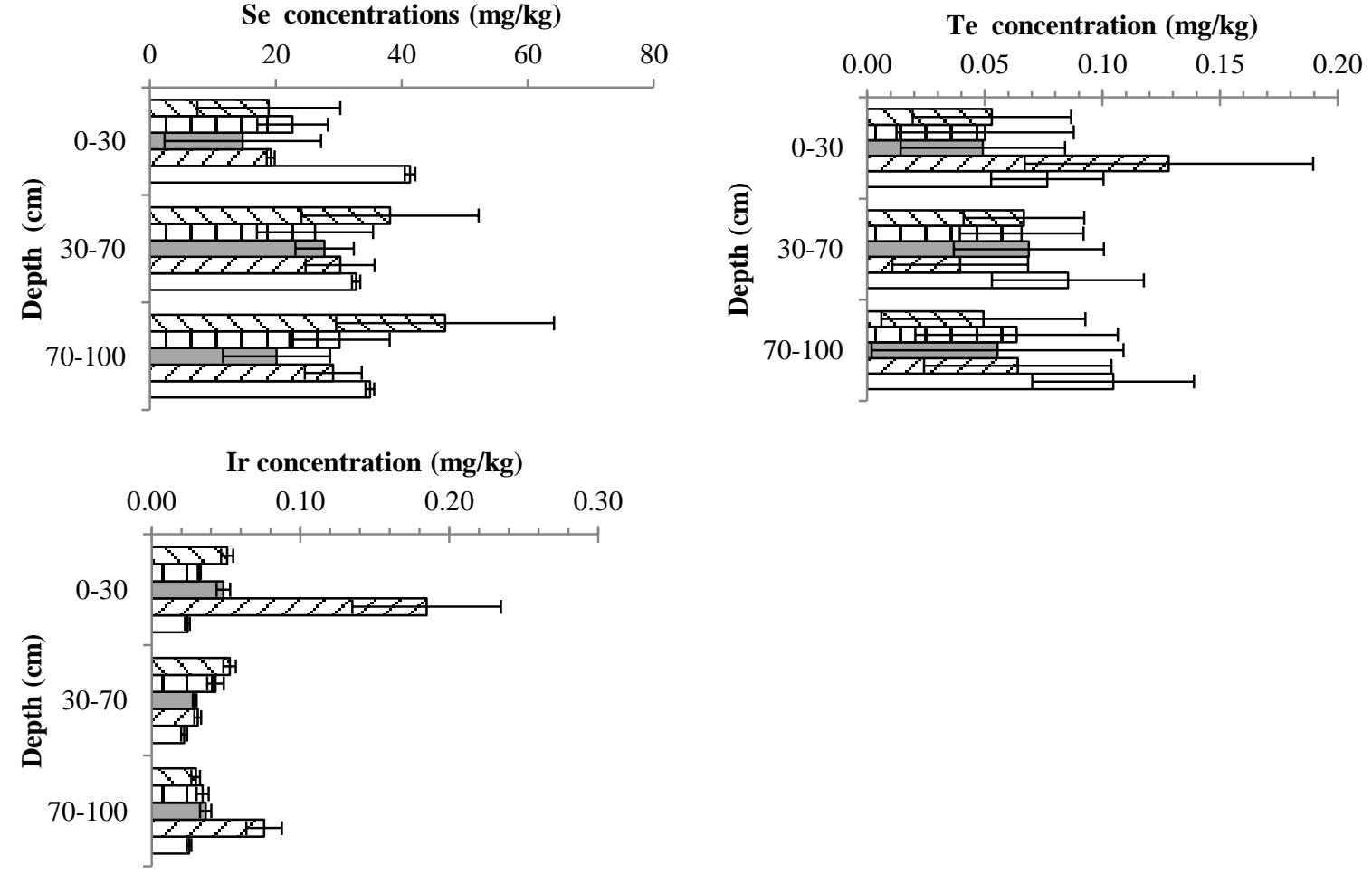

Fig. S4.Concentrations (mg/kg) of metals (As, $\mathrm{Li}, \mathrm{Co}, \mathrm{Be}, \mathrm{Se}, \mathrm{Te}$, and Ir) at site 1-1, site 1-2, site 1-3, and site 1-4 at three depths of soils amended by biosolids. Error bars represent one standard deviation of measured samples. The metals exhibit trends similar to those of Pt and Ce. 


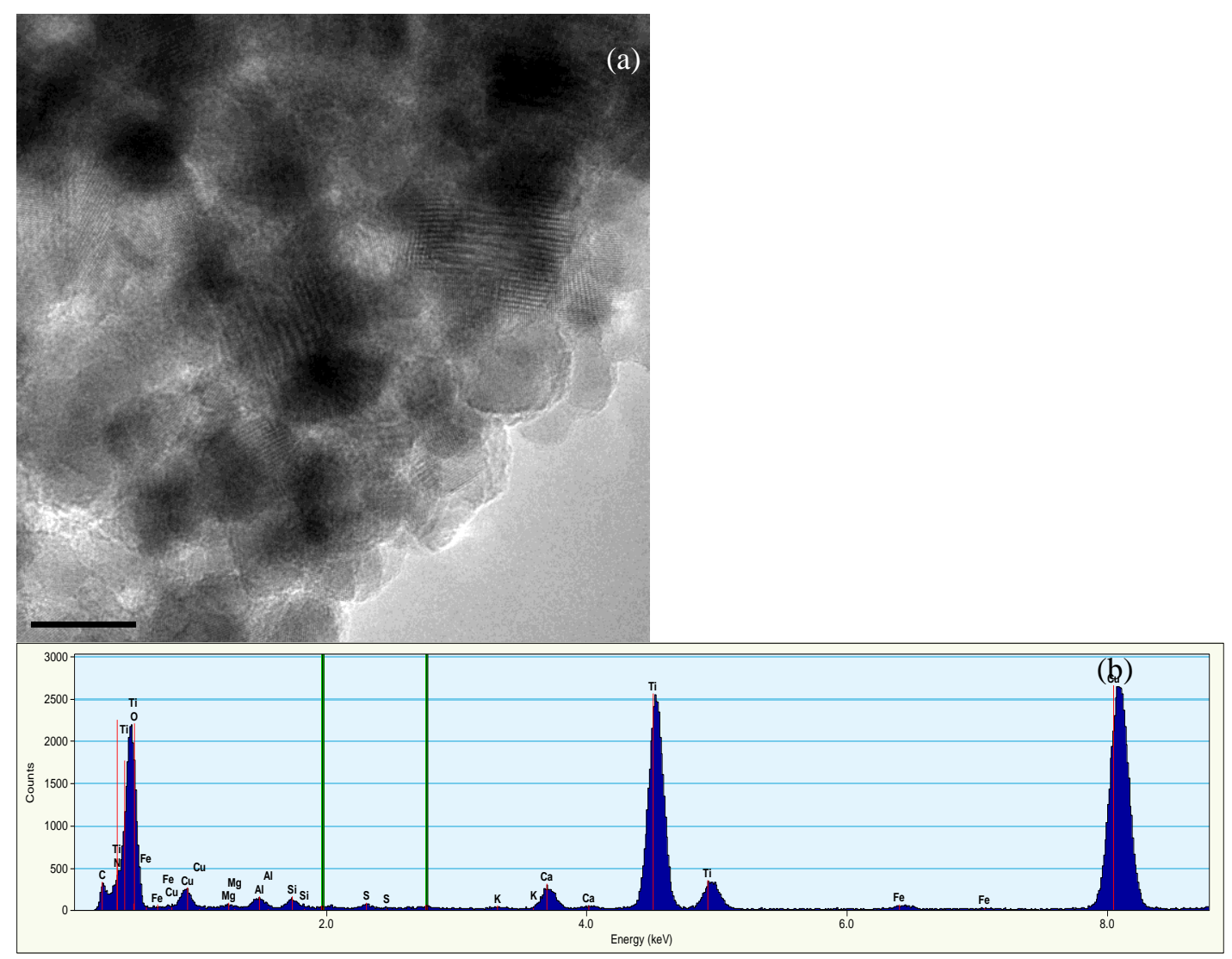

Fig.S5. (a)Transmission electron microscopy (TEM) image and (b) energy dispersive x-ray spectroscopy (EDX) of titanium dioxide particles embedded in soil (0-15 cm, Field D32, Belton, TX). 


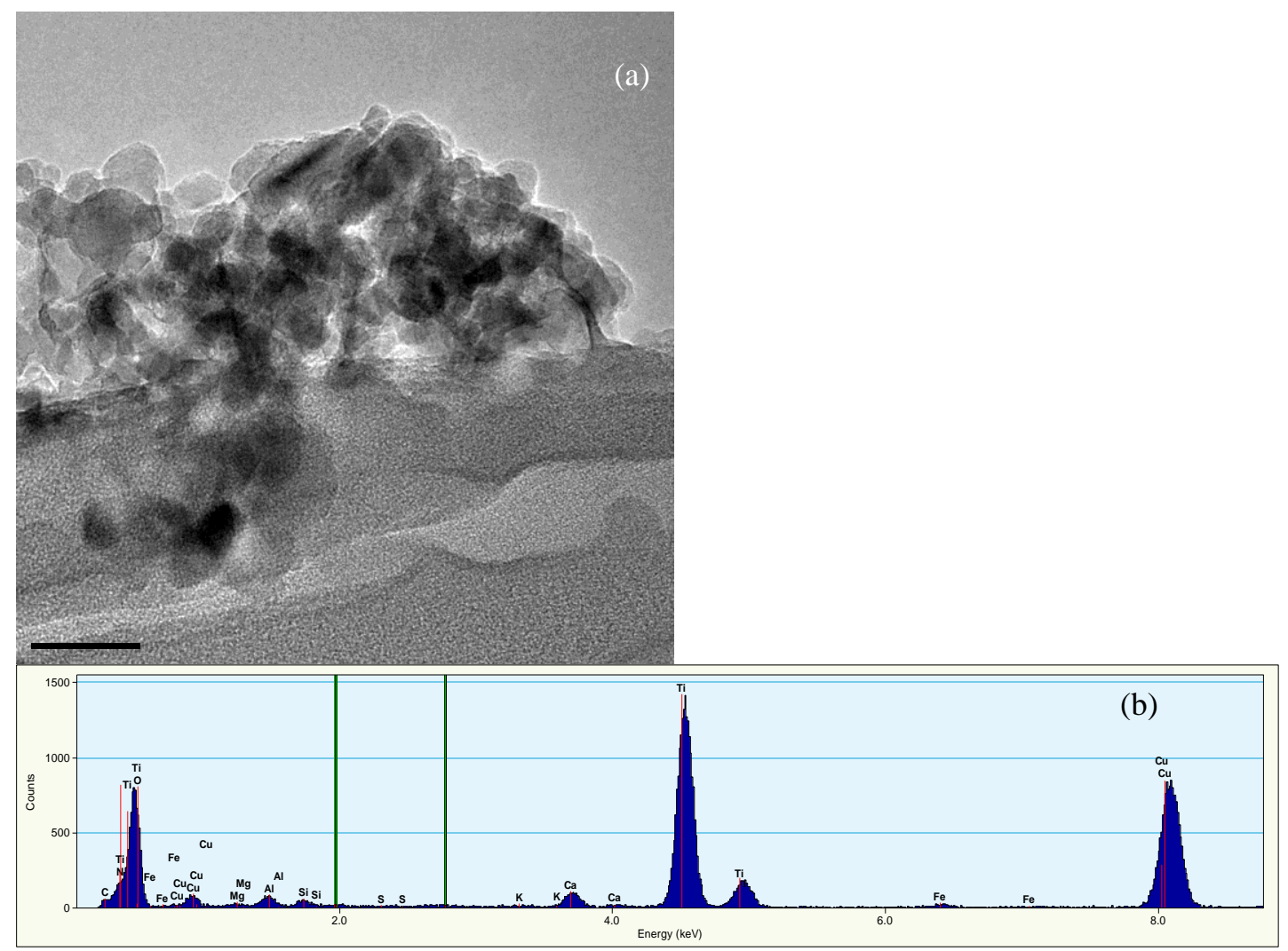

Fig.S6. (a) Transmission electron microscopy (TEM) image and (b) energy dispersive x-ray spectroscopy (EDX) of titanium dioxide particles embedded in soil $(0-15 \mathrm{~cm}$, Field D32, Belton, TX). 

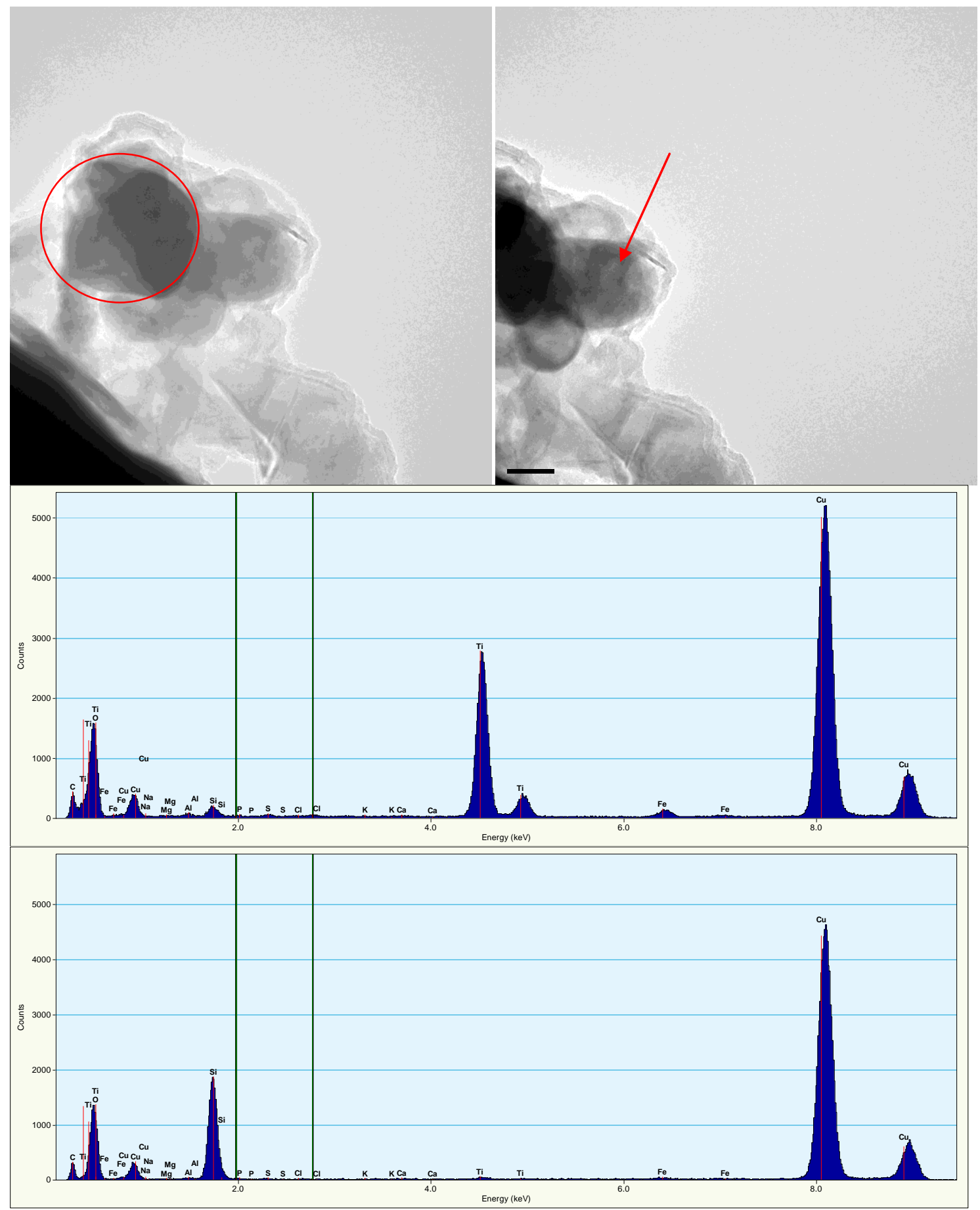

Fig.S7.Transmission electron microscopy (TEM) images and energy dispersive x-ray spectroscopy(EDX) of titanium dioxide particles and silicate particles embedded in soil.(a) TEM image of $\mathrm{TiO}_{2}$ particles, (b) $\mathrm{TEM}$ image of $\mathrm{SiO}_{2}$ particles, (c) $\mathrm{EDX}$ of $\mathrm{TiO}_{2}$ particles, and (d) EDX of $\mathrm{SiO}_{2}$ particles. Samples were from 0-30 cm layer of site 1-3. 